American University Washington College of Law

Digital Commons @ American University Washington College of

Law

Articles in Law Reviews \& Other Academic Journals

Scholarship \& Research

2013

'Simple' Takes on the Supreme Court

Robert Tsai

Follow this and additional works at: https://digitalcommons.wcl.american.edu/facsch_lawrev

Part of the Communications Law Commons, First Amendment Commons, Legal Ethics and

Professional Responsibility Commons, Legal History Commons, and the State and Local Government Law Commons 


\section{"Simple” TAKes On the Supreme Court}

This paper can be downloaded without charge from The Social Science Research Network
Electronic Paper Collection "Simple" Takes On the Supreme Court

\section{Robert L. Tsai}

This essay assesses black literature as a medium for working out popular understandings of America's Constitution and laws. Starting in the 1940s, Langston Hughes's fictional character, Jesse B. Semple, began appearing in the prominent black newspaper, the Chicago Defender. The figure affectionately known as "Simple" was undereducated, unsophisticated, and plain spoken - certainly to a fault according to prevailing standards of civility, race relations, and professional attainment. But these very traits, along with a gritty experience under Jim Crow, made him not only a sympathetic figure but also an armchair legal theorist. In a series of barroom conversations, Simple ably critiqued the ongoing project of liberal legal experimentation. In fact, Simple had something to say on many matters of constitutional law: the injustice and absurdity of racial violence and segregation, the agonizing pace of integration, the limitations of the nation's civil rights laws, and the dwindling effectiveness of street protests. Fiction became a two-way legal medium, teaching citizens about the U.S. Constitution, while giving them a way to puncture the lofty yet cramped official interpretations of the law. Through arguments, stories, and dream sequences, the author proposed a conception of equality rooted in authenticity, charity, and opportunity, to counteract the vision of selective, formal equality emerging from the Supreme Court. As an alternative, he recommended a transitional form of poetic justice to effectuate the ethical and material transformation necessary to guarantee equal protection of the law.

I. THE WORKING MAN'S BAR OF JUSTICE................................................... 38

A. Simple as Legal Theorist ................................................................. 40

B. Dreams of Self-Governance ........................................................ 43

II. TAKING ON THE SUPREME COURT ……….......................................5

A. Remaking Equality ................................................................ 54

* Professor of Law, American University, Washington College of Law. Copyright (C) 2012 by Robert L. Tsai. All rights reserved. This paper was originally prepared for the 2012 Conference on "The Art and Politics of Irony," sponsored by the Institute for the Public Life of Arts and Ideas at McGill University. Thanks to Susan Carle, Garrett Epps, and Paul Yachnin who offered helpful comments, as well as to Darren Hutchinson, who introduced me to Simple's world. This essay benefited from the research assistance of Meghan Connell, Joe Hernandez, Ashlee Hodges, Veronica Jae, and Addison Pierce. 
B. A Role for Poetic Justice.

III. THE LIMITS OF DIRECT ACTION

IV. CRITIQUING SimPLE’s CONSTITUTIONAL VISION

Oh, if every Negro in America, big and small, great and not so great, would just take his clothes off and keep them off for the sake of civil rights, America would be forced to scrutinize our cause. -Jesse B. Semple ${ }^{1}$

In November 1942, the American poet Langston Hughes began writing a weekly column in the Chicago Defender. ${ }^{2}$ The next year, he introduced a character named Jesse B. Semple, who rapidly became a vehicle for critiquing issues of interest to the black community. ${ }^{3}$ Semple was born in Virginia but relocated to Harlem, straddling the two worlds. ${ }^{4}$ One is still haunted by the legacy of slavery; the other is undergoing a black renaissance yet remains a place where more subtle forms of inequality are woven into the fabric of everyday life. ${ }^{5}$ Over the years, the character affectionately nicknamed "Simple" for his unsophisticated views and unvarnished way of speaking the truth arguably became "the most famous character in black fiction" and Hughes's "greatest contribution to American culture." 6 The character turned out to be so vividly rendered that fans would address mail to Simple rather than his creator. ${ }^{7}$ As Hughes's column was syndicated, republished in the New York Post, and then collected in a series of books, more and more Americans gained insight into an intra-community discussion over race relations, democratic justice, and legal developments. Der-

1. Langston Hughes, Pose-Outs, in Simple's Uncle Sam 107, 109 (1965) (internal quotation marks omitted)

2. ARNOLD RAMPERSAND, THE Life OF LANGSTON HUGHES 53 (2nd ed. 2002)

3. Id. at 61-87.

4. Langston Hughes, Feet Live Their Own Life, in Simple SpeaKS HIS Mind (1943); LANGSTON Hughes, $A$ Toast to Harlem, in SiMPLE SPEAKS HIS MIND supra, at 31.

5. See generally HUGHES, supra note 4

6. Donna Akiba Sullivan Harper, Not So Simple: The Simple Stories by Langston HUGHES 3 (1995) (internal quotation marks omitted). See also RAMPERSAD, supra note 2, at 113; Julian C. Carey, Jesse B. Semple Revisited and Revised, 32 PHYLON 158 (1971); Melvin G. Williams, Langston Hughes's Jesse B. Semple: A Black Walter Mitty, 10 Negro AM. LiT. ForUm 66 (1976).

7. There is even a student note in the Harvard Law Review attributed to "Jesse B. Semple" according to citations. See, e.g., Kathryn Abrams, Title VII and the Complex Female Subject, 92 Mich. L. REv. 2479, 2494 n.44 (1994); Reginald Leamon Robinson, The Racial Limits of the Fair Housing Act: The Intersection of Dominant White Images, the Violence of Neighborhood Purity, and the Master Narrative of Black Inferiority, 37 WM. \& MARY L. REV. 69, 127 n.273 (1995); Frank Rudy Cooper, Against Bipolar Black Masculinity: Intersectionality, Assimilation, Identity Performance, and Hierarchy, 39 U.C. DAVIS L. REV. 853, 865 n.53 (2006). A closer inspection, however, reveals that the name of the note's author is omitted according to the Harvard Law Review's conventions and that the piece begins with a quote attributed to Jesse B. Semple. See Note, Invisible Man: Black and Male Under Title VII, 104 HARV. L. REV. 749 (1991). Scholars and student editors unaware that Semple is a fictional character must have listed him as the author. 
rick Bell became so enamoured of Simple that he updated the character and used it as a fictional interlocutor in his own stories. ${ }^{8}$

To laugh along with Simple, as Arthur Davis suggests, is to engage in a form of therapy over our own clichéd thinking on matters of race. ${ }^{9}$ But there is more: a rich account of law and politics shared through humor and good sense. This essay explores how the character of Simple emerged as a crucial medium in the black community for working out popular understandings of the law. ${ }^{10}$ Through dialogue, satire, the occasional poetry, and even extended fantasy, ${ }^{11}$ the author conveys the depths and complexity of African American attitudes toward everything from the failure to end lynching to the U.S. Supreme Court's efforts to mold an integrated society. ${ }^{12}$ By developing a sophisticated politics of irony, he does his part to promote democratic justice. Simple takes on defenders of racial apartheid, ${ }^{13}$ as well as the tactics of civil rights protestors engaged in direct action. ${ }^{14} \mathrm{He}$ wonders why it took so long for the government to fulfill what the plain text of the Constitution promised, muses about remedies that the Supreme Court stubbornly refused to consider, ${ }^{15}$ and expresses frustration at intergenerational injustices yet to be acknowledged. ${ }^{16}$

Careful exegesis of Simple's stories can enrich our appreciation for how constitutional visions can be sustained or deconstructed beyond the walls of the courthouse. At their best, extant theories of popular constitutionalism have encouraged researchers to look past the myth of judicial review and examine how actors shape the meaning of the Constitution outside of the

8. See Derrick A. Bell, Faces at the Bottom of the Well (1992) [hereinafter Faces]; Derrick A. Bell, Jr., A Holiday for Dr. King: The Significance of Symbols in the Black Freedom Struggle, 17 U.C. DAVIS L. Rev. 433 (1984) [hereinafter A Holiday for Dr. King]. See generally CAROL E. Henderson, America AND the Black Body: Identity Politics in PRint and Visual Culture 3841 (2009). In A Holiday for Dr. King, Bell tells of a story of an encounter with a cab driver named "Jesse B.," supposedly named after Langston Hughes's famous character. In this encounter, Bell plays the straight man (as Boyd did in Hughes's stories) as the cabbie drives him through the ghettos of Harlem on his way to the airport. Bell's second-generation Simple has a harder edge, telling him that the Emancipation Proclamation and other proclamations are nothing but "bogus freedom checks that [the Man] never intends to honor." Bell, supra, at 434-35. He sees Martin Luther King Day as "the latest gimmick white folks have come up with to keep dumb blacks satisfied." Id. at 434 . His tone is "more strident," he speaks "with deadly seriousness," and lacks the sense of rueful humor and playfulness of the original Simple character. Id. at 436. In his book, FACES AT THE BOTTOM OF THE WELL, Bell turns Simple into a spokesperson for a black homeland outside of the United States. FACES, supra, at 29-30. To make the character align more closely with a critical race perspective, then, Bell renders Simple more despondent of liberalism and more open to racial sovereignty.

9. Arthur P. Davis, Jesse B. Semple: Negro American, 15 PHYLON 21, 21 (1954).

10. I have previously analyzed how Langston Hughes's poetry develops a melancholy ethics on behalf of the democratic citizen. See Robert L. Tsai, The Ethics of Melancholy Citizenship, 89 OR. L. REV. 557 (2010).

11. See Sam G. Riley, Langston Hughes's Jesse B. Semple Columns as Literary Journalism, 10 AM. PERIODICALS 63, 71-75 (2000) (analyzing literary devices employed by Hughes in stories about Simple).

12. See generally, HuGHES, supra note 4.

13. Id.

14. Id

15. Id.

16. Id. 
courts. ${ }^{17}$ Many have focused on the behavior of institutions, social movements, and high officials, or they have tried to measure the extent to which judicial rulings are backed by public opinion. ${ }^{18}$ Yet despite enlarging the field of inquiry, non-judicial approaches to legal change have sometimes suffered from being overly formal, elite, or unidirectional. Many approaches have been hampered not only by methods, but also by sources. To accurately discern how constitutional ideas permeate the population and are in turn reworked by average people, we must look beyond judicial rulings and official texts and toward popular writings, orations, and underground literature.

Examining how black fiction manipulates legal ideas makes it possible to broaden the field of action in which legal ideology is developed, the range of potential constitutional actors who manipulate understandings of the law, and the types of texts that reinforce or subvert the law. The exercise helps us to see, in the domain of popular culture, how legal knowledge can be made accessible and relevant to the experience of ordinary people. One can learn how sustained criticism of constitutional visions emerge from below, in places far removed from the formal processes of law. Such cultural systems can be every bit as tenacious as the justice system in shaping public understandings of foundational texts. In fact, alternative legal texts may play an even greater role for a community that has experienced significant democratic injustices but lacks the ability to push and pull the levers of power.

\section{THE WORKING MAN’S BAR OF JUSTICE}

For a theory of law to be truly popular, it must be understandable by the common man. On that score, the Simple stories easily satisfy the criteria of accessibility and salience. From the outset, Hughes positions his famous character as a man of the people. Simple describes himself in humble terms, as "not that smart and far from high educated," a "broom pusher."19 It is through his rich dialogue with others that he reveals himself as engaged, ornery, demanding. During the course of conversations with a narrator later given the name "Boyd," Simple works through conflicting reactions

17. See, e.g., Barry Friedman, The Will of the PeOPle: How Public Opinion Has INFLUENCED THE SUPREME COURT AND SHAPED THE MEANING OF THE CONSTITUTION (2009); LARRY D. Kramer, The People Themselves: Popular Constitutionalism and Judicial ReView (2005); Gordon Silverstein: LaW's Allure: How Law Shapes, Constrains, SAVES, and Kills Politics (2009); Mark Tushnet, Taking the Constitution Away From the Courts (2000); Keith E. WhitTington, Constitutional CONSTRUCTION: Divided Powers and CONSTitutional Meaning (1999); Bruce Ackerman, The Living Constitution, 120 HARV. L. REV. 1737 (2007); Mark A. Graber, Popular Constitutionalism, Judicial Supremacy, and the Complete Lincoln-Douglas Debates, 81 CHI.KENT L. ReV. 923 (2006); Reva B. Siegel, Dead or Alive: Originalism as Popular Constitutionalism in Heller, 122 HARV. L. REV. 191 (2008).

18. See, e.g., Lee Epstein et al., The Supreme Court During Crisis: How War Affects Only Non-War Cases, 80 N.Y.U. L. REV. 1 (2005).

19. LangSton Hughes, Face and Race, in Simple Stakes A Claim 58, 59 (1957) (internal quotation marks omitted). 
to a number of social issues of the day. ${ }^{20}$ He may drink and ramble his blues away but make no mistake: there is something significant going on. ${ }^{21}$ By having their fictional encounters take place in a local watering hole, the author sets the stage by subverting the reader's expectations. ${ }^{22}$ Unlike so many institutions that have let down African Americans (including the legal system), the bar is dependable. "I can lean on this bar," Simple asserts, "but I ain't got another thing in the U.S.A. on which to lean." 23 A bar might not be the type of place where one would imagine serious discussion of political or legal issues to occur but that sort of endless democratic conversation is in fact what the author portrays. ${ }^{24}$ The drinking establishment is where the common man can be found after the end of a long workday, lending the talks a degree of informality, authenticity, and intimacy. In the freewheeling atmosphere of the tavern, beyond the peering eyes of the state, all men are truly equal.

Matters that might be discussed with tight-lipped gravity in other settings can be approached in this site of democracy with bawdy humor, outrage, profanities - the kind of reactions that might seem uncivil, ungrateful, uppity, or dangerous elsewhere. Perhaps more cautious or diffident in polite society, Simple bravely "stakes [his] claim" to freedom on a nightly basis while he nurses a drink. ${ }^{25}$ Through Simple's regular judgments on political and legal controversies, the local bar is transformed into the common man's "bar of justice." 26 Buying a beer for a thirsty fellow waiting on his paycheck is appreciated as the ultimate act of kindness, a form of equality rooted in charity for all.

In the company of friends and strangers, Simple develops a distinctive politics of irony. Practitioners within the legal system-judges and lawyers, bureaucratic actors - typically cannot deploy sarcasm, irony, or humor in the course of their official duties. Institutional expression must be authoritative, measured, instrumentally directed, and calibrated to the precise institutional roles expected of them. ${ }^{27}$ If legal actors were to conduct themselves otherwise, they would risk being misunderstood, ignored, or defied. By contrast, popular legal discourse can be wide-open, profane, and even fantastic to achieve any number of desired reactions: shock, sympathy, outrage, disgust, disappointment, action. Martha Nussbaum explains that

\footnotetext{
20. Phyllis R. Klotman, Jesse B. Semple and the Narrative Art of Langston Hughes, 3 J. NARRATIVE TECH. 66 (1973) (analyzing skit technique employed by Hughes).

21. Phyllis R. Klotman, Langston Hughes's Jess B. Semple and the Blues, 36 PHYLON 68 (1975).

22. Davis, supra note 9, at 27-28.

23. LangSton Hughes, Something to Lean On, in Simple Speaks His Mind, supra note 4 at 176, 178 (1943).

24. Id.

25. Langston Hughes, Color on the Brain, in Simple Stakes a Claim, supra note 19, at 106, 107.

26. "My place is at the bar," Simple tells Boyd. "Of Justice?" Boyd asks. "Justice don't run no bar," Simple responds. LANGSTON Hughes, Income Tax, in SimPle SPEAKS His Mind, supra note 4, at 119,125 (1943) (internal quotation marks omitted).

27. Howard SchweBer, The LANGUAGE OF Liberal CONSTitutionalism (2007).
} 
"[1]iterature is in league with the emotions." 28 And yet, to the extent that such a medium can harness the emotions to expose gaps between law and experience and stimulate a more searching debate over the purpose of the law, fiction can serve the ends of public rationality.

In the hands of an adept author such as Langston Hughes, fiction acquires a dual orientation towards the law. It can promote popular acceptance of the rule of law, insofar as an artistic work takes certain legal texts or principles as authoritative. In those moments, the work of art reinforces the goals of a normative community to reproduce itself and its values. At the same time, the Simple stories uncover the inner workings of the law as an "empire of force," and foster an anti-establishment ethic to counteract a culture that sustains lawful violence against human beings. ${ }^{29}$ They do so by recovering the dignity of those who suffer legal violence, uncovering the extent of damage wrought by the law, and pointing out missed opportunities for democratic justice. ${ }^{30}$ For Hughes, this process must entail reimagining existing institutions, starting with the transformation of a private establishment into the working man's bar of justice.

\section{A. Simple as Legal Theorist}

If the bar has been re-imagined as a site of deliberation and resistance, it is also because the setting and characters model an ideal of legal pluralism. $^{31}$ The defining characteristic of legal pluralism is the belief that the vitality, justness, and efficacy of the law can only be ensured through contest among differing understandings, commitments, and priorities. ${ }^{32}$ Hughes's stories offer an account of law, and the Constitution in particular, from "the bottom part" of the U.S.A. ${ }^{33}$ Simple's legal perspectives are often contrasted with that of Boyd, his straight man, who represents a patriotic, middle class point of view. The narrator is an upwardly mobile "colleged" black, whose interests align well with the integrationist model of law. ${ }^{34}$ Boyd supports the liberal vision of equality as "colorblindness," regularly

28. Martha C. Nussbaum, Poetic Justice: The Literary Imagination and Public Life 53 (1995).

29. James Boyd White develops Simone Weil's evocate phrasing beyond a condition that makes war possible, into a mindset that facilitates any legal coercion, implicating the "psychological, emotional, and ideological." James BOYd White, LiVING SPEeCh: Resisting THE EMPIRE OF ForCe 5 (2006). See also Desmond Manderson, Trust Us Justice: 24, Popular Culture, and the Law, in IMAGINING LEGAlitY: WhERE LAW MEETS POPUlAR CUlTURE 27 (Austin Sarat ed., 2011) (describing popular culture as "a site of resistance" to the law).

30. See generally HUGHES, supra note 1.

31. See Sally Engle Merry, Legal Pluralism, 22 LaW \& SoC'Y. Rev. 869 (1988); John Griffiths, What is Legal Pluralism?, 24 J. Legal PluRALISM \& UNOFFICIAL L. 1, 3 (1986).

32. See generally Merry, supra note 32.

33. HugHES, supra note 19 , at 59 .

34. LangSton Hughes, Concernment, in SimPle's UnCle SAM, supra note 1, at 146, 152. In an interview, the author suggests that the two characters' dialogue represents tensions within himself and his community: "The character of my Simple Minded Friend ... is just myself talking to me. Or else me talking to myself." HARPER, supra note 6, at 58 (quoting Langston Hughes, Simple and Me, 6 PHYLON $349,349(1945))$ 
giving voice to the aspirational dimension of American citizenship. ${ }^{35}$ By contrast, Simple is a proud "race man . . . Till the day I die — since I will be black until I am buried," leading Boyd to accuse him of having "color phobia," being a "racial isolationist," "nationalist," and "black chauvinist." 36 Simple retorts, "You got one thing right ... I am black.",37

Representing the liberal hope in enlightened progress, the narrator longs for the day that the past is not only conquered, but also forgotten. Instead of dwelling on contemporary injustice, Boyd thinks only of the future, advising Simple to rise "above the struggle" and "ignor[e] the petty things of this world." 38 Beyond suggesting that they must let bygones be bygones, Boyd believes in the uniform application of law. ${ }^{39}$ His character captures the lawabiding citizen who is generally risk-averse, quick to point out the foolishness, dangers, or costs of Simple's proposals for achieving democratic justice. Ideally for Boyd, as for other proponents of legal liberalism, constitutional change should occur in an orderly and incremental fashion, through the normal operation of the legal and political system. ${ }^{40}$ Even the smallest deviation from establishment expectations of how citizens ought to behave troubles Boyd.

Simple's wife, Joyce, also serves as a vivid counterpoint, showing how tensions in the black community over ideology and tactics must be negotiated even within the basic family unit. ${ }^{41}$ She is an "intellect," interested in the arts, and constantly pushing Simple to attend book talks and organizational functions. ${ }^{42}$ While Joyce is involved in civic activities to help fellow blacks "take away their country ways and prepare them for big-city days," ${ }^{43}$ Simple would prefer to remain a passive member of the NAACP, which has taken the lead in suing racists and organizing boycotts. ${ }^{44}$ Boyd uncritically vocalizes positions one might expect of individuals interested in getting along and getting ahead, whereas Joyce captures the up-by-one's-bootstraps tradition in the black community, believing that moral uplift will render the law an increasingly unnecessary tool. ${ }^{45}$ Joyce constantly seeks to civilize Simple, reshaping him according to the norms of a black urban lifestyle. For Simple, spending so much time in the bar is as much a rejection of this civic project as it is a preference for the informal, semi-anonymous companionship found in a tavern.

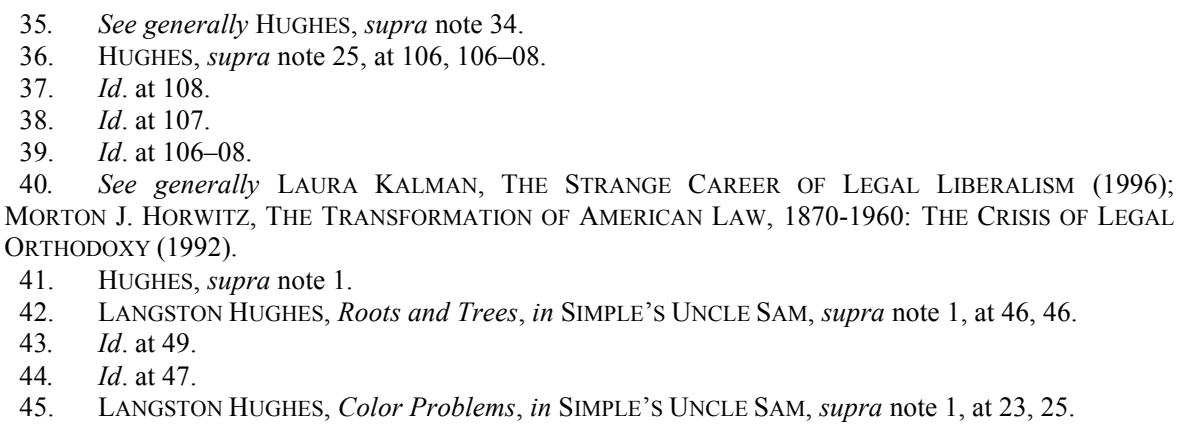


Simple is an idea man; a theorist, not an activist. Cousin Minnie, who is the agitator in the family, takes to the streets to demand, "Freedom now!" 46 Eschewing traditional activism along with the project of inward regeneration, Simple's bemused detachment allows him to function as an effective legal critic. By freeing himself from permanent associations other than his racial identity, he is at liberty to attack democratic injustice, official hypocrisy, and even black complacency. His ironic detachment allows him to "get with the nitty-gritty, wise up and be witty"-virtues he finds desirable in a citizen of urban democracy. ${ }^{47} \mathrm{He}$ can, by turns, credibly lacerate white America's institutions for failing to live up to ancient legal promises and poke fun at the priorities of black leaders. And more than merely undermining official conceptions of law, he is well-situated to present alternative readings of the nation's most important laws.

There is irony in the fact that some of the people most knowledgeable about legal rights are those least able to enjoy them. "The Constitution guarantees us equal rights," Simple insists, demonstrating his facility with the nation's fundamental principles and making a demand for legal satisfaction. " "[B] ut have I got 'em? No. It's fell down on me. . . Just like it fell down on that poor Negro lynched last month."49 He plays on the phrase "fall down" to bring the nation's highest laws down to earth, where the oppressed can be found. Whether there is even such a thing as law and order, much less equality of citizenship, turns on whether legal rules can offer basic safety and dignity for average Americans. If there is a major disconnect between higher law and their lived experience, Simple's ruminations propose to repair that rupture.

Though Simple shares a common rage with black radicals, he differs from black nationalists who insist that the Constitution has no claim upon African Americans in the United States. Simple sees the abstractions contained in the nation's liberation texts as valuable and universal ideals, even as he points out that the promises have been poorly kept:

Now, the way I understand it . . . it's been written down a long time ago that all men are borned equal and everybody is entitled to life and liberty while pursuing happiness. It's in the Constitution, also Declaration of Independence, so I do not see why it has to be resolved all over again. ${ }^{50}$

Simple makes a twofold point: these particular legal principles are inviolable and it takes something more than speech to ensure compliance. The

46. LANGSTON Hughes, Wigs for Freedom, in SimPLE's UnCle SAM, supra note 1, at 139, 142.

47. HUGHES, supra note 46 , at 48 .

48. Langston Hughes, The Law, in Simple SpeaKs His Mind, supra note 4, at 178.

49. Id.

50. Id. at 192. On the rise of competing theories of interpretation that emerge from an early republican consensus, see H. Jefferson Powell, The Original Understanding of Original Intent, 98 HARV. L. REV. 885 (1985) 
enormous gap between lofty aspirations and legal action is captured in his mantra, "Resolving ain’t solving."

\section{B. Dreams of Self-Governance}

Simple's unsettled state allows him to imagine ways black Americans can make a difference someday. In a number of stories, Simple tells Boyd about a dream he recently had, and in these moments, the two ponder the possibilities for black empowerment. ${ }^{52}$ These dream sequences-always rendered from Simple's point of view and uniformly fantastic - are full of legal import. As Simple explains, "it dreams so good to imagine again in my sleep that I am the ruler of Dixie, me, colored and all my people, in charge of the state we Negroes helped to make so beautiful." ${ }^{, 53}$ During sleep, one can keep alive the fragile dream of self-governance, even when the daytime is characterized by the despair of disempowerment. After a hard day of work, the evenings can be filled with the festive sharing of democratic dreams.

How might political power be used if African Americans one day gained political clout? Rendering democratic justice would be at the top of the agenda. In the vignette For President, ${ }^{54}$ Simple declares that he is contemplating a run for the Presidency now, since he predicts (somewhat presciently) "there might be a Negro President in the year 2011" and it would no longer be cool to seek higher office. ${ }^{55}$ If he were elected President, the first thing he would do is "decree Alabama, Georgia, Mississippi, and Louisiana out of the Union." 56 In dreams, of course, one can envision the possibility of democratic justice without worrying too much about legal limits. Put aside any constitutional restrictions on presidential power: as Chief Executive, Simple would hand those states to the Devil to "straighten them out," but he would show mercy to all the dogs. ${ }^{57}$ A presidential rescue of Southern canines would show him to be a wise leader, since Simple elsewhere laments that segregationists in the South treat blacks worse than they treat animals. $^{58}$

51. HuGHES, supra note 57, at 192.

52. See, e.g., LANGSTON HugHES, Rude Awakening, in SimPle's UnCle SAM, supra note 1, at 127.

53. HUGHES, supra note 61 , at 240.

54. LAngston Hughes, For President, in The LATER Simple StORIES, supra note 61, at 187, 187.

55. Id.

56. $\quad I d$. at 188 .

57. Id. On the dangers of constitutional dictatorship, see Jack Balkin, Constitutional Dictatorship: Its Dangers and Its Designs, 94 MinN. L. REV. 1789 (2010); Bruce Ackerman, The Emergency Constitution, 113 YALE L.J. 1029 (2004).

58. Simple observes on another occasion that during the days of slavery, "a good bloodhound was worth more than a good Negro, because a bloodhound were trained to keep the Negroes in line. If a bloodhound bit a Negro, nothing were done to the dog. In fact, Negroes were supposed to be bit." LANGSTON Hughes, Dog Days, in Simple's UnClE SAM, supra note 1, at 103, 105. "Even a black dog gets along better than me," Simple laments. "White folks socialize with dogs-yet they don't want to socialize with me." LANGSTON Hughes, Equality and Dogs, in SiMPLE SPEAKS HIS Mind, supra note 4, at 152, 152. "White dogs and black dogs all served together in the army, didn't they?" Id. at 153. 
Simple's dreams and ruminations revolve around several interlocking themes: combating a theory of white self-rule, exposing the hypocrisy of legal officials, exploring the wisdom of black empowerment, and questioning integration as the sole measure of democratic justice.

1. Dethroning White Sovereignty. A recurring theme in the stories involves combating the principle of white sovereignty, the belief that being born into White America entails not only the right to govern, but to exclude and oppress non-whites through the law. "God made both of us," Simple reminds, "[b]ut white people in the U.S.A. has got the upper hand-the whip hand-which they have had since the days of slavery." 59 "This theory of law and politics, which called upon the people to deny the natural state of equality, long ago infected legal decision making. The Supreme Court notoriously endorsed that concept in Dred Scott v. Sanford ${ }^{60}$ when it denied Congress the power to regulate slavery and deprive masters of their "property." 61 Brown v. Board of Education ${ }^{62}$ may have spelled the beginning of the end of the government's endorsement of white sovereignty, but alone the decision could not transform the value systems of average white Southerners. ${ }^{63}$ Simple repeatedly suggests that racial sovereignty is a distinctly American belief: "White folks are not jackasses in Europe." ${ }^{64}$

Like other critical black writers, such as Ralph Ellison, Hughes believes that art can disrupt the neat, Manichaeistic belief system upon which racial power relies: white and black, wise and unsophisticated, innocent and guilty, just and unjust, order and chaos. ${ }^{65}$ In The Moon, Simple attacks the notion that racial sovereignty leads to happiness or prosperity. ${ }^{66}$ His strategy is to undermine the logic of white power by testing its claim to superior virtue. $^{67}$ In doing so, he puts the moral quality and practical consequences of politics ahead of any desire for cultural purity or racial solidarity:

"White is right," said Simple, "so I have always heard. But I never did believe it. White folks do so much wrong! Not only do they mistreat me, but they mistreats themselves. Right now, all they got

59. LAngSton Hughes, Haircuts and Paris, in Simple's UnCle SAM, supra note 1, at 63, 63.

60. 60 U.S. 393 (1857).

61. See id. at $451-52$.

62. 347 U.S. 483 (1954).

63. On white sovereignty in American law, see MARK GRABER, DRED SCOTT AND THE PROBLEM OF CONSTITUTIONAL EVIL (2006); ROBERT L. TSAI, AMERICA'S ForgotTEN CONSTITUTIONS: DEFIANT VISIONS OF POWER AND COMMUNITY (2014).

64. HugheS, in SimPLE'S UnCLE SAM, supra note 71, at 64. "In Europe they accepts colored peoples as human beings," Simple explains. Id. "Therefore Negroes can get their hair cut anywhere in any barbershop in Paris, France, or Rome, Italy, or Madrid, Spain. Also Negroes can get shaved. Here in the United States to get shaved, a white barber is liable to cut a colored man's throat instead of trimming his beard." Id. Once again, the character distills the inequity of segregation to tangible experiences, while hinting at the violence entailed in enforcing a vision of white sovereignty in everyday life.

65. See Jack Turner's incisive essay on Ellison's theory of "disinterested love" as a measure of democratic citizenship, Awakening to Race: Ralph Ellison and Democratic Individuality, 36 POL. THEORY 655 (2008).

66. LANGSton Hughes, The Moon, in Simple's UnCLE SAM, supra note 1, at 27, 27-29.

67. Id. 
their minds on is shooting off rockets and sending up atom bombs and poisoning the air and fighting wars and Jim Crowing the universe. $^{68}$

Having shown that white rule does not necessarily lead to wise rule, the character then exposes the absurdity of white sovereignty by suggesting that segregationists might well wish to keep outer space a black-free zone:

I have not heard tell of no Negro astronaughts nowhere in space yet. This is serious, because if one of them white Southerners gets to the moon first, COLORED NOT ADMITTED signs will go up all over heaven as sure as God made little green apples, and Dixiecrats will be asking the man on the moon, 'Do you want your daughter to marry a Nigra?' Meanwhile, the NAACP will have to go to the Supreme Court, as usual, to get an edict for Negroes to even set foot on the moon. ${ }^{69}$

Taking it a step further, Simple wonders whether "them Southerners will take police dogs to the moon," which would then surely prompt Freedom Riders to shoot themselves into orbit to convey the people's outrage. ${ }^{70}$ After the reader stifles a chuckle, one sees that this extended "fantasy" is intended to show how racial hatred as well as love for others is in fact "a many-splintered thing." " tions are regulated by race laws, the author reminds the reader that segregationists' dedication to their principles knows few bounds. The scenario also reveals the folly of racial separation. "Jim Crowing the universe" 72 would entail restricting black-white relations in a place few people might ever set foot, and where meaningful social contact would be difficult in the absence of major technological advances. Taken to its logical extreme, the project of white sovereignty can be exposed for its absurdity and waste. Law itself, harnessed to reshape our surroundings according to some racialized vision, becomes devoid of meaning-directionless, lacking sense, illegitimate.

2. Exposing Hypocrisy. Nothing enrages Simple more than hypocrisy on the part of the authorities or their abject failures to enforce the law. ${ }^{73}$ In matters of liberty and equality, he delights in showing how the left hand often does not know or does not care what the right hand is doing. ${ }^{74}$ From his skeptical perch on the bar stool, Simple contends that such inconsisten-

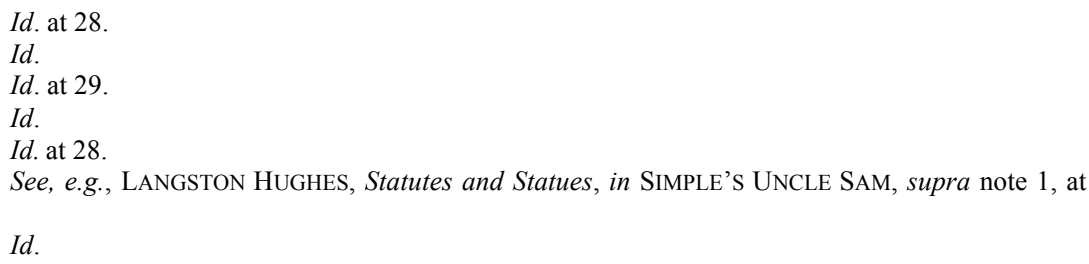


cies undermine the legitimacy of race-based laws. ${ }^{75}$ Reversing the age-old position that blacks needed to be civilized, Simple insists that white Americans are the ones today in need of better home training: "White folks at times can certainly be contrary," but "[t]hat is no way to behave in our democratic day and age," he admonishes. ${ }^{76}$

In one humorous passage, he notes that all day long, Southern Governors preach against race-mixing, "[t]hen, after nightfall, them governors themselves start mixing as hard as they can." 77 These same elected officials abhor intermarriage, but say precious little about all that "inter-mating" going on in the dark. According to Simple's diagnosis of segregation, the law cannot be taken seriously when its enforcers do not live their own legal positions, in private as well as in public. To suggest that the law does not have independent integrity is an implicit critique of process-based theories of the law, which hold that democratically enacted measures are imbued with sufficient legitimacy so as to render the law's inconsistencies merely secondorder problems. ${ }^{78}$ To the contrary, the author demands greater harmony between the actions of a law's proponents and their legal commitments. The legitimacy of the law turns on its moral content, backed by regular enforcement. It is a high standard, to be sure, but one that accords with his ethically-based theory of law.

Simple becomes furious when, during a dream about the afterlife, he is met at the Gates of Heaven by both St. Peter and the "Old Governor of Mississippi, Alabama, or Georgia, or wherever he is from." entry and tells him to use the Colored Entrance around the back. ${ }^{80}$ Simple's greatest nightmare has come to pass: "White folks have done got up there and made an American out of Saint Peter" and somehow found a way to racialize God's eternal law. ${ }^{81}$ For Simple, divine law has been corrupted by a distinctive, racial nationalism. ${ }^{82} \mathrm{He}$ is told by the Old Governor: "You are not inside yet, Simple. Therefore, you are still black. White is right, black get back!" 83 Uncharacteristically driven to action, Simple threatens to beat them both with his wings. ${ }^{84}$ St. Peter intercedes and admonishes, "Jesse B.,

\footnotetext{
75. See generally LANGSTON HugheS, Simple's UnCLE SAM, supra note 1.

76. LANGSton Hughes, Reason and Right, in Simple StaKes a Claim, supra note 19, at 147, 147.

77. Langston Hughes, With All Deliberate Speed, in Simple StaKes a Claim, supra note 19, at $67,67$.

78. For process-based theories of law, see JOHN HART ELY, DEMOCRACY AND DISTRUST: A THEORY OF JUDICIAL REVIEW (1981); Herbert Wechsler, Toward Neutral Principles of Constitutional Law, 73 HARV. L. REV. 1 (1959).

79. LANGSTON HUGHES, Golden Gate, in SiMPLE’s UNCLE SAM, supra note 1, at 94, 95.

80. Id. at 95 .

81. Id. at 97 .

82. He makes the point that racial sovereignty is culturally specific with characteristic flair: "White folks are not jackasses in Europe,' says Simple. 'In Europe they accepts colored peoples as human beings." HUGHES, supra note 71.

83. HUGHES, supra note 95, at 95-96.

84. Id. at 96 .
} 
we go for nonviolence in heaven." 85 Meanwhile, the Old Governor's spirit runs off to look for his dogs to sic on Simple. ${ }^{86}$

This scene underscores the theme of hypocrisy in enforcing the laws, with authorities saying one thing while doing another. While St. Peter represents the aspirational, benevolent face of the law, the Old Governor signifies legal violence untethered from principle. Simple's dream reveals how white power can corrupt higher law. Illustrating how the moral authority of the law can become diluted, St. Peter throws up his arms and explains to Simple, "Heaven is so full of white folks now I have no control over it any more." 87 The dream dissipates with Simple rallying the dearly departed to defend their dignity and threatening to tear down the Golden Gate. But, leaving the fate of the law unresolved, the sequence ends before any listeners can respond to his call to action.

In another flight of fancy, Simple shares a dream he had in which panicked blacks trample a white woman as everyone rushes to a bomb shelter. ${ }^{88}$ Diagnosing the situation, Boyd tells Simple he must have been "[g]etting rid of your hostilities" and "working out your own evil by way of a dream." 89 Boyd's statement flags the possibility that legal racism has an impact on the imagination of citizens - yet another cost of this type of democratic injustice.

Simple ultimately decides that the trampling scenario could never happen in the South because they would likely build no shelters for blacks, and "[i]f they did, it would be a little old Jim Crow shelter in Uncle Tommy's back yard meant just for handkerchief heads." ${ }^{90}$ Boyd shakes his head in disbelief, as he often does, at Simple's stories of racial injustice: "Do you mean to tell me the white South would be so inhumane as to build public bomb shelters with signs up WHITE ONLY, and none for Negroes?" 91 As a Northerner, the narrator often expresses shock at the lengths to which segregationists would go to protect white self-rule. Boyd is never sure what is the truth, given Simple's penchant for exaggeration. By the end of the story, one's attention has been turned away from the horrors of segregation back to Simple's ludicrous dream, with the all-black survivors in the bomb shelter making the best of a frightening situation, "singing and shouting the

85. Id.

86. Hughes returns to the idea of segregationists who dream of an all-white Heaven in Cracker Prayer. LangSton Hughes, Cracker Prayer, in SimPle's UnCle Sam, supra note 1, at 124, 125. There, he imagines how a mean "old cracker" would pray to the Lord: "Lord, if there be educated Nigras in heaven, keep them out of my sight. The only thing I hate worse than an educated Nigra is an integrated one.... As You is my Father, Lord, lead me not into black pastures, but deliver me from integration, for Thine is the power to make all men as white as snow." Id.

87. HUGHES, supra note 95 , at 95 .

88. Langston Hughes, Atomic Dream, in Simple's UnCle SAM, supra note 1, at 54, 54.

89. Id.

90. Id.

91. Id. at 55 . 
blues." 92 In this way, the author reminds his readers of the indefatigable capacity of black Americans to survive legal inequities.

3. Facilitating Black Empowerment. Black powerlessness remains a related theme in the stories, despite the improving legal condition of African Americans. "The Constitution, the government, the law are now all on the Negro's side," Boyd notes optimistically. ${ }^{93}$ "But is Uncle Sam?" wonders Simple. ${ }^{94}$ Noting that Uncle Sam is always depicted as a white man, he states, "Uncle Sam do not have to sue in the Supreme Court every time he wants to get a cup of coffee down South ... Neither do Uncle Sam have to sue in Mississippi every time he wants to vote." 95 There have been white leaders sympathetic to the plight of blacks-Roosevelt, Kennedy, Johnson-but the fate of the black community has all too often depended on the grace of others.

Not so in Simple's imagination. At night, he keeps alive the possibility of black participation in self-rule. ${ }^{96}$ In one dream sequence, African Americans have taken over the South, and Thurgood Marshall has risen to Chief Justice of the Supreme Court. ${ }^{97}$ The Court has helped whites by "granting everybody the right to file another suit to get their rights." " Engaging in a bit of wry role reversal, Simple is portrayed as a rich man who says:

Just because a handful of old Negroes wearing robes in the Supreme Court says your rights are constitutional, it does not mean they are institutional. Our great institutions like the University of Jefferson Lee belong to us, and not even with all deliberate speed do we intend to constitutionalize the institutionalization of our institutions. $^{99}$

He observes that legal values must become entrenched to be effective. Simple's play-acting as a member of an imagined black majority does not go too far, though he has fun ordering "Mammy Faubus" to fix him a mint julep and fetch his palm-leaf fan. ${ }^{100}$

Interestingly enough, Frank Johnson, a white Fifth Circuit judge who dutifully enforced desegregation orders at great personal cost, is recast (in a seemingly honorific artistic gesture) as a colored jurist who nevertheless

92. Id. Elsewhere, the character expresses his fear that if he were in Mississippi, "I would be Jim Crowed out of bomb shelters, so I would need some kind of protection." LANGSTON HuGHES, Radioactive Red Caps, in SIMPLE STAKES A ClAim, supra note 19, at 53, 54. But the legal process being as slow as it is, Simple continues, "[b]y the time I got the NAACP to take my case to the Supreme Court, the war would be over, else I would be atomized." Id.

93. LANGSTON HUGHES, Uncle Sam, in SiMPLE’s UNCLE SAM, supra note 1, at 176, 177.

94. Id.

95. Id.

96. HUGHES, supra note 61, at 127.

97. Id.

98. Id. at 130 .

99. Id.

100. Id. at 132 . 
helps white protestors by issuing nominal fines. ${ }^{101}$ But, alas, the white youths would not be helped, saying they would rather stay in jail until they can eat in "fine black barbecue joints where white folks never been known to eat before." 102 The moral of the story is that when blacks finally get to enjoy political power, they can be counted upon to exercise wisdom and justice, unlike their white counterparts. Before anything transpires to ruin the vision of black rule, however, daybreak comes and Simple "woke up to the same old nightmare." 103

4. Beyond Integration. One of Simple's consistent critiques of the law is that it has all too often been distorted to preserve the comfort and sensibilities of white Americans. ${ }^{104}$ His recommendations for how to subvert the system are uniformly hilarious, if a bit shocking.

Simple launches a devastating, multi-prong attack on the liberal program of integration. For the sake of argument, he treats integration as a serious goal, but doubts that the authorities are sufficiently committed to substantive equality. ${ }^{105} \mathrm{He}$ believes that for true integration to be effective, it would require "a fuse, else a blowtorch," to ensure that prejudice is "[n]ot just melted down, but burnt up." 106 No trace of race prejudice could remain in a constitutional order characterized by democratic justice. Because liberals show little stomach for such social engineering, integration must instead be about improving appearances - and promoting equality as a form of civility. Simple rejects this conception of equality as insufficient to render democratic justice. ${ }^{107}$ Merely seeking to create the appearance of social equality, as the courts do through busing orders, is a superficial goal and ultimately corrosive of social ties.

Simple has a similar critique of bans on interracial marriage, though this time he accuses white politicians of stoking the politics of distraction. ${ }^{108}$ His position on the controversy is straightforward: despite all the huffing and puffing of white leaders, law has no place in this realm. ${ }^{109}$ "All a white girl has to do to keep from marrying a Negro is to say, 'No," he points out matter-of-factly. ${ }^{10}$ Simple himself is twice married, having earlier had a youthful marriage break up. ${ }^{111}$ The issue of marriage whips people up, and he says that he has "got a great many other things to worry about besides intermarriage." 112 Though he chides politicians for making so much out of

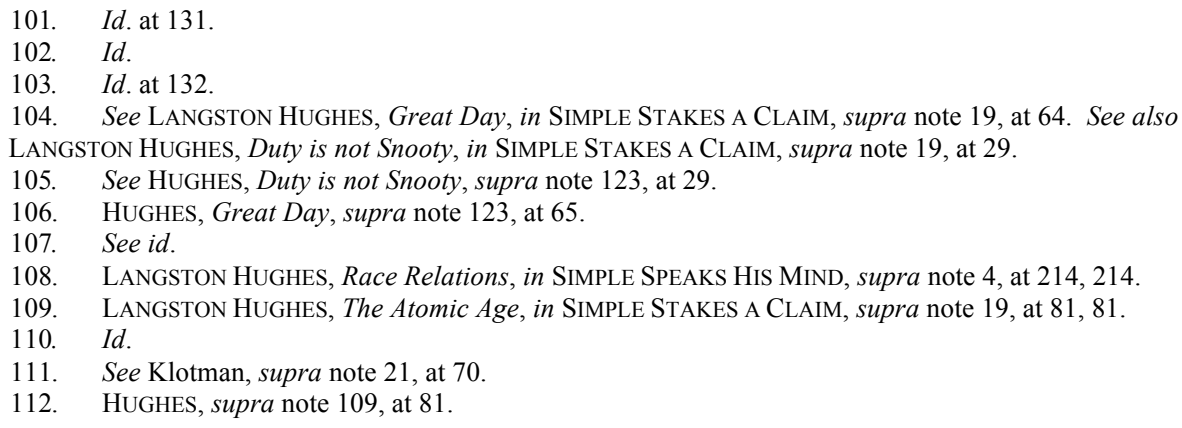


the issue, the more he thinks about it, the more he comes to the realization that a pro-interracial marriage position may be best for racial harmony in the long run. ${ }^{113}$ Significant numbers of white men and black women may oppose intermarriage at the moment, "[b]ut if the races are ever going to relate, they must also mate, then you will have race relations." 114 To reinforce the sense that his idea merely recognizes existing social practice, Simple points out that "the South has always done more relating than anybody else. There are more light-skinned Negroes in the South whose pappy was a white man than there is in all the rest of this whole American country." 115 So, there is hope.

It is hard to know how seriously the character takes his own proposal to fuse families in the name of good order, for racial mixing behind closed doors has gone on longer than official policies of racial separation. But the pun allows him to air a perspective - and a solution - surely considered taboo in many quarters. And he reminds, once again, that social integration shouldn't be an empty slogan, but rather a plan with very real consequences. ${ }^{116}$ If biology is political destiny, as some argue, then perhaps the theory can be put to use in the name of democratic justice.

Beyond getting the law out of private domains (or at least matching actual social practice), Simple's pleas for racial equality can be quite modest: "I wants me a train-station toilet with everything in it everybody else has got." 117 He unmasks the Supreme Court's infamous ruling in Plessy v. Ferguson $^{118}$ as a thinly-disguised effort to promote white comfort at the expense of black indignities. ${ }^{119}$ "There is nothing like a COLORED toilet in a Southern train station! Half the time, no mirrow, no paper towels, sometimes no sink even to wash your hands. They is separate, all right, but not equal." 20 By reducing the complaints of black Americans to such a visceral level, he makes the question of equality one of truly basic human (in)dignity.

Reinforcing this theme of bodily indignity elsewhere, ${ }^{121}$ he tells a ridiculous, sad story about a black G.I. who has to go to the bathroom so badly he has no time to wait for the colored latrine to become free. ${ }^{122}$ When a white M.P. threatens to shoot him if he enters the white latrine, the black soldier brandishes his own weapon in order to answer nature's call. ${ }^{123}$ The

113. HUGHES, supra note 127, at 214

114. Id. at 215.

115. Id. at 215. Not only do these ideas gesture toward the older but prevalent American mixing pot ideal, it also accords with the more provocative Ellisonian position that all Americans are mulattoes. See Turner, supra note 78 , at 669-72.

116. HUGHES, supra note 127 , at 216.

117. HugHeS, Great Day, supra note 123 , at 30.

118. Plessy v. Ferguson, 163 U.S. 537 (1986), overruled by Brown v. Bd. of Educ., 347 U.S. 483 (1954).

119. See Hughes, Great Day, supra note 123, at 29-32.

120. Id. at 30 .

121. HUGHES, supra note 26, at 122-23.

122. Id.

123. Id. at 123 . 
point is not simply that segregationists are foolhardy for trying to stand in the way of human nature. It is also a reminder about the violence that lies at the heart of legalized inequality. That the loyal black soldier must resort to his own show of force serves as a reminder that even the smallest legal disruption may expose resistors to danger or punishment.

The most infamous legal arguments on behalf of Jim Crow invoke the state's police power to fight crime or to preserve the moral welfare of the people. According to this empirically-oriented approach, blacks are presumed to have a propensity for criminality, or racial unrest is reasonably likely to break out when social mixing occurs. ${ }^{124}$ Simple sees the public order argument as nothing more than a cynical ploy to retain white privilege. He lashes out at those who claim that racial separation promotes the peace: "What kind of peace are you talking about? That is the trouble with you white folks, always wanting peace, and I ain't got no privileges. You are always keeping the best of everything for yourself. All the peace is on your side." ${ }^{25}$ In his takedown of segregation, he also challenges the law's claim of neutral decision making. ${ }^{126}$ Though seemingly neutral in the abstract, the public order argument is anything but race-neutral in practice. Whenever the social order argument is trotted out, blacks are invariably cast as disturbers of the peace, and white property, convenience, and sensibilities are consistently treated as a segregated society's prize possessions. ${ }^{127}$ The fruits of "peace" are available to be savored only by the white majority.

If Simple held a position of authority, he would entertain creative, even extreme measures to defend the constitutional rights of black Americans. $\mathrm{He}$ is all for public spectacle to bring down segregation, the more spectacular, the better. "For freedom's sake - and adventure," he would arrange tours of the "Savage South" for white Northerners. ${ }^{128}$ He would make sure whites run into blacks in order to guarantee adventure. The ads might read: "SPECIAL RATES FOR A WEEK-END IN A TYPICAL MISSISSIPPI JAIL. Get arrested now, pay later. Bail money not included. Have the time of your lives living the life of your times among the Dixie White Skins."129 It readily becomes apparent that Simple believes commercial tourism can serve the ends of political activism. With a twinkle in his eye, he predicts that "[i]f . . . the white old folks go as sight-seers ... no sooner than they got down there, they would be Freedom Riders anyhow," joining the student-led protests. ${ }^{130}$

Congress, usually counted upon by whites for the vindication of their rights and interests, gets very little treatment in the stories. That is likely because until the mid-1960s, Congress was not perceived as hospitable to

124. See, e.g., Plessy v. Ferguson, 163 U.S. 537, 549-51 (1896).

125. See LANGSTON HugheS, Puerto Ricans, in SimPle StaKeS A Claim, supra note 19, at 73, 75.

126. See id. at 73-76.

127. Id.

128. LANGSton Hughes, Adventure, in Simple's UnCle SAm, supra note 1, at 66, 66-68.

129. Id. at 68 .

130. Id. 
minorities. ${ }^{131}$ The institution's failure to pass a civil rights bill stands as poignant evidence of congressional detachment or downright hostility. Simple has a few choice words for colored congressmen who stand by while "them old white Southerners filibuster [each civil rights bill] to hell and gone." ${ }^{32}$ When Boyd reminds him that it takes many people to keep a filibuster going, this only whips Simple into a frenzy. ${ }^{133}$ If he were a member of Congress, he "would filibuster to keep them filibusters from starting a filibuster." 134 He would keep the fate of his race foremost in his mind:

for my people I would talk until my tongue hung out of my mouth. I would talk until I could not talk no more! Then, I would use sign language. When I got through with that, I would get down on my knees and pray in silence. And nobody better not strike no gavel while I am communicating with my Maker. ... I would be the greatest one-man filibuster of all time, daddy-o! ${ }^{135}$

Simple has some bills in mind, should legislative gridlock ever be overcome. One of his proposals involves Congress enacting "a few Game Preserves for Negroes." "136 It is not as if the strategy has not been used before for endangered species: "The government protects and takes care of buffaloes and deers-which is more than the government does for me or my kinfolks down South." 137 He explains that the federal government "ought to set aside some place where we can go and nobody can jump on us and beat us, neither lynch us nor Jim Crow us every day. Colored folks rate as much protection as a buffalo, or a deer."138 Simple deftly turns legal separation from a dehumanizing practice into a policy that would meet humanitarian objectives. In making the case for a sanctuary, he harkens to older dreams of a black homeland on American soil. ${ }^{139}$ What about the risk of a filibuster? Simple thinks Southerners would be glad to get rid of blacks, but then "who would they lynch?" 140

Because of the failures of an unwieldy, hostile Congress, and only occasional help from friendly presidents, ${ }^{141}$ blacks have come to rely heavily on

131. See Warren M. Christopher, The Constitutionality of the Voting Rights Act of 1965, 18 STAN. L. REV. 1, 1-5 (1965) (explaining Congress's history of inaction on minority issues).

132. Langston Hughes, For the Sake of Argument, in Simple SpeAKS His Mind, supra note 4, at $185,189$.

133. Id. at 189

134. Id.

135. Id. at $189-90$

136. Langston Hughes, There Ought to Be a Law, in SimPle SPEAKS HIS Mind, supra note 4, at $114,115$.

137. Id.

138. Id. at 116.

139. TSAI, supra note 76

140. HUGHES, supra note 155 , at 117

141. It is telling, though, that Eleanor Roosevelt is accorded privileged status in Simple's mind, winning several references for her pro-equality stances, while her husband gets barely any mention. 
the legal system. It is to Simple's imaginative takeover of the Supreme Court and its vision of legal justice that we now turn.

\section{TAKING ON THE SUPREME COURT}

The United States Supreme Court is a fixture in the Simple stories, illustrating how all eyes were on that institution, before and after Brown. ${ }^{142}$ That African Americans have had to resort to the courts time and again is an indictment of white voters and evidence of the fragility of liberal progress. Simple longs "to see the day when I would not have to hire a lawyer to go to the Supreme Court to eat in a restaurant in Virginia." 143

While litigation became the primary approach to securing the rights of African Americans, Simple's stories suggest that not everyone in the black community was comfortable with this focus, nor confident of meaningful progress. The Supreme Court frequently serves as a foil, to dramatize the different possible popular reactions to its interpretations of the nation's fundamental law. ${ }^{144}$ After Brown is decided, Simple shares his mixed feelings in Great but Late. ${ }^{145}$ While it is certainly the right decision, "'It's about time' says Simple." $146 \mathrm{He}$ is particularly incensed by the self-congratulatory reactions to the case: "I don't see nothing to be proud of-just doing what they ought to do." 147 He likens the situation to a person who has had a foot on someone's neck for so long and then cried, "Ain't I wonderful! I took my foot off your head!"148 Instead of beating their chests for the courageous decision, whites "ought to be ashamed of themselves for Jim Crowing us so long. I might have had a good education myself had it not of been for white folks." triumphalism, would be consistent with genuine remorsefulness. Since these sincere sentiments are lacking (and not demanded by the Court's own ruling), it is hard to believe that a true transformation in social relations has occurred.

Moreover, litigation is expensive for the oppressed, and segregationists themselves have spent untold millions resisting legal progress. And all for what? "[A] step forward for people who was so far back" but hardly a step ahead. ${ }^{150}$ In fact, the judicial ruling represents only a first step, and a modest one at that: "All they done is start to catch up —and they're putting that

142. E.g., Hughes, supra note 61, at 127; LANGSTON Hughes, Jim Crow's Funeral, in SIMPLE STAKES A CLAIM, supra note 19, at 118, 120.

143. HugHES, Jim Crow's Funeral, supra note 161, at 118, 120.

144. See LANGSton Hughes, Great but Late, in Simple StAKes A Claim, supra note 19, at 33.

145. Id.

146. Id. at 33

147. Id.

148. Id. at 35 .

149. Id. at 33

150. Id. 
off until sometime in the future when they can work things out with all deliberate speed." "I51 In other words, never.

The theme of the law merely relegating blacks to playing catch-up with whites is a powerful criticism of the Warren Court. ${ }^{152}$ But it goes even deeper, as it captures a popular impatience with inadequate liberal solutions. On this view, the Justices settled for glory and the easy win by trying to engineer integrated schools rather than attempting a more comprehensive but infinitely more challenging solution to racial injustice. ${ }^{153}$ An intergenerational violation of the Constitution requires an intergenerational remedy, Simple says, but desegregation orders benefit only current and future students. ${ }^{154}$ Simple finds himself among the class of ordinary people left out: "I am happy ... for all the colored kids still going to school and all the folks still in the South," he explains. ${ }^{155}$ "But what about the folks as old as me who went to them ramshackle old beat-up shacks they had for colored schools down home all this time?"156 One alternative would be courtordered compensation for those denied an equal education. "If they want something to be proud of," Simple demands, "let them pay me for all the education I ain't got." 157 That compensation has been taken off the table for older African Americans demonstrates how (not so) far activists and judges are willing to go.

In a larger sense, Simple's character symbolizes missed opportunities for American law. The law's achievements should be measured according to tangible gains, not merely the vindication of worthy abstractions. When Boyd gushes that "Negroes today are being rapidly integrated into every phase of American life," Simple reminds him that "I have not advanced one step .... Still the same old job, same old salary, same old kitchenette, same old Harlem and the same old color." 158 Through that short colloquy, he declares it his duty, as much as it is the responsibility of elites, to shine the light on the areas unreached by the Constitution.

\section{A. Remaking Equality}

A coherent theory of equality can be stitched together from Simple's bar room commentary. Although the character's views are expressed piecemeal over decades, they emerged from the pen of a single public intellectual who had long engaged legal and political questions through his art. Four elements make up Hughes's popular conception of equality: authen-

151. Id.

152. See Louis Michael Seidman, Brown and Miranda, 80 CALIF. L. REV. 673 (1992).

153. Id. at 709-17 (arguing that Brown reflects the Court trying to resolve the "dilemmas of liberal individualism" by backing away from more radical forms of social restructuring in favor of short-term symbolic gains in promoting racial neutrality and individual dignity).

154. See HuGHES, supra note 163, at 34.

155. Id.

156. Id.

157. Id. at 33 .

158. HUGHES, supra note 111, at 53. 
ticity, reciprocity, charity, and opportunity. Equality must arise from authentic sentiments rather than merely being compelled by others. Beyond placing a limit on what government can do, sincere actions taken in the name of equality must foster reciprocal relationships. Charity must replace civility as the ideal for the ties among citizens. It follows that ending discrimination can be only an opening step; a meaningful opportunity to pursue the good life must represent the ultimate end of democratic justice.

In the vignette, Empty Houses, ${ }^{159}$ Simple articulates his conception of equality, which differs significantly from the pursuit of equal protection of the law then underway in the legal system. ${ }^{160}$ At its heart is the idea of generosity, exhibited when something of value is freely given. He describes an instance when, as a young boy, a white man bought him an ice cream cone on a hot day, "without being asked or hauled up before the Supreme Court."161 This unremarkable act of kindness was all it took to ensure he does not "hate all white folks today." "162

Though Simple believes more must be done to ensure equality, he is not a mindless leveler. He derides overly formal theories of equality, especially "[t]it for tat" expectations that accompany any demand for equality of outcomes:

Some folks think that everything in life has to balance up, turn out equal. If you buy a man a drink, he has to buy you one back. If you get invited to a party, then you have to give a party, too, and invite whoever invited you. My wife, Joyce, is like that - which makes folks end up having to give parties they do not want to give, and going to a lot of parties to which they do not want to go. ${ }^{163}$

Simple warns against theories that require equality of outcomes, which can produce not only gratuitous behavior, but also inauthentic gestures. ${ }^{164}$ Formal equality not only encourages inefficient uniformity, but also superficiality. Instead of civility or mindless tit-for-tat treatment, equality is better stripped down to a more basic expression of charity. Distilled to its essence, the purest form of equality is selflessness. Buying a beer for someone who is thirsty may seem like a very small thing, perhaps even nothing. But "[n]othing is everything," says Simple, "when it comes from the heart." 165 The best evidence of true equality is when citizens treat each other with kindness without the compulsion of law.

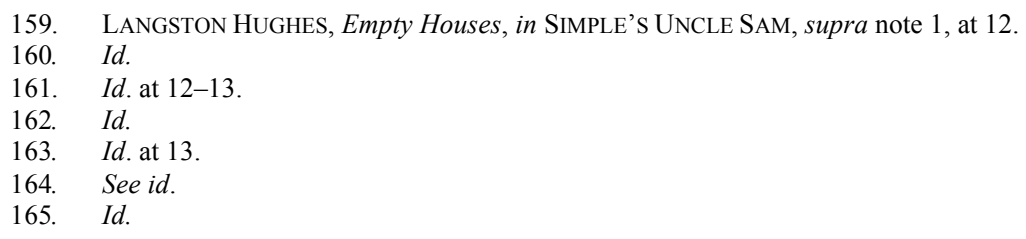


This emphasis on the virtues of authenticity and charity confirms an ethical alternative to the Supreme Court's notion of equality as fair treatment. As a dissenting theory of equality, Simple's vision attacks the emerging juridical concept of equality as right conduct for being utterly impoverished. To read the Equal Protection Clause ${ }^{166}$ as requiring merely fair treatment of others is to not demand enough of fellow citizens. For Simple, the cramped juridical concept of equality is evidence that the High Court has abandoned the moral project of law. One only seeks to regulate behavior within narrow bounds after giving up on the possibility of ethical transformation, believing it too hard to alter cultural attitudes. Simple not only argues that robust equality is required by the Constitution, he also denies that it is an impossible task. Thus, his reduction of the lofty aims of equality to common, visceral terms serves a twofold purpose: to make democratic justice accessible to more Americans and to deal with the lingering problem of political despair.

If a thoughtless back-and-forth characterizes one type of danger presented by formal equality, hateful reprisals comprise another. Only lasting ethical change can help the community avoid the pitfall presented by any project of democratic justice: the politics of resentment. Though Simple jokes a great deal about the deeply entrenched attitudes of whites, he grasps that the politics of resentment are toxic. One problem with formal equality is that it fosters the mindset that equality is a zero-sum game: that any improvement for blacks necessarily comes at the expense of whites. There must be a way out of this destructive cycle of tit-for-tat, though escape cannot come at the cost of equal opportunity.

Making anti-discrimination the heart of equality, as elites have done, ${ }^{167}$ is insufficient to spark an ethical transformation. For one thing, it is a piecemeal approach, a requirement of fair treatment in select contexts. For another, a person must already be advantaged-possess a job, a home, prospects-before the principle of anti-discrimination can do much good. Without these antecedent events or tangible opportunities, civil rights laws do little for the average black citizen. "The NAACP and the unions is wrestling over color bars in employment . . . but there is no color bar in unemployment" Simple complains, pointing out the narrowness of the civil rights agenda. ${ }^{168}$ "When a man is unemployed and out of work, be he black or white, his pockets is equally empty." 169

Simple thus suggests a way forward by turning to material improvement and enhanced opportunities after ethical transformation has begun to take

166. U.S. CONST. amend XIV, § 1 .

167. See, e.g., ANDREW KopPELMAN, ANTIDISCRIMINATION LAW \& Social EQUALiTy 8 (1996) (identifying antidiscrimination as the primary route through which to foster a culture of equality); Paul Brest, The Supreme Court, 1975 Term-Foreword: In Defense of the Antidiscrimination Principle, 90 HARV. L. REV. 1 (1976).

168. HUGHES, supra note 35 , at 146.

169. Id. 
hold. ${ }^{170}$ According to this vision of the law, true equality means rectifying untended economic inequities. ${ }^{171}$ Previously unseen structural conditions reinforce racial subjugation. Without either ethical or material change, no amount of tinkering with the law can truly level the playing field. At the same time, thinking of rights in economic terms offers a tantalizing possibility for overcoming a zero-sum mindset, in which every gain for the oppressed entails a loss for everyone else. Apart from death, Simple implies, poverty is the great equalizer. ${ }^{172}$ Race may never become irrelevant to American law, but the sooner that the authorities turn their attention to improving the material conditions of citizens, the more likely that support for democratic justice will emerge.

None of these ruminations on equality means that Simple opposes court-centered jurisprudence or civil rights, only that he feels that activistdriven, judicially managed solutions fail to reach many of the gritty, everyday interactions among the people. ${ }^{173}$ In this sense, his humanistic critique of the law exposes legal liberalism's limits. Judicial decisions rarely impact the most intimate interactions between human beings. Unless coercion is cleverly applied, it is unlikely to produce a change of sentiment. Grudging obedience falls short of true equality. Compulsion can breed false charity or feigned toleration rather than an authentic change of heart as to the intrinsic dignity of fellow human beings. Simple certainly has no sympathy for the segregationist who "gets hot under the collar when the Supreme Court edicts an edict that don't stick." ${ }^{\prime 14}$ Ultimately, Simple believes that equal dignity must somehow bloom in the dark places far away from the glare of public litigation and the media. ${ }^{175}$

One of Simple's major complaints is that judge-centered justice has blinded officials and ordinary Americans to the injuries suffered by blacks who are not currently in school. ${ }^{176}$ Legal solutions, in other words, have not been popular enough in terms of coverage and support among the constituencies of democratic justice. In this way, he reminds readers that the problem of race is an intergenerational one that requires a remedy of the same magnitude: "We are a broke race of people," Simple announces, a collective financial state that must be laid at the foot of a legal system that for so long protected slaveholders and white supremacists. ${ }^{177}$ His preferred legal remedy is reparations: "I am all for trying to collect what is owed my great grandpa and grandma from slavery days for all that free labor my ancestries did in this American country!"178 True to his nature, Boyd raises statute-of-

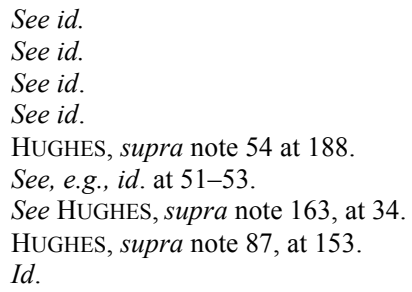


limitations problems, but for Simple, procedural obstacles can never stand in the way of higher law obligations taken on by the people. When unjust enrichment of this scale is involved, the remedy must match the violation.

\section{B. A Role for Poetic Justice}

Simple goes beyond articulating a popular concept of equality to rival what is developing in the courts. He also articulates what a satisfactory remedy might entail, issuing his own judicial decrees. In these moments, he ventures into presenting an account of ideal judging and a striking brand of poetic justice.

On several occasions, Simple fantasizes about how to ensure that white Americans actually commit to practicing equality in the long run. In the $1950 \mathrm{~s}$, at the height of desegregation, he toys with the idea of role-reversal as the key to promoting structural change. His recommendation: "White folks that love me and care about my race ought to sleep in colored hotels when they travel."179 According to Simple's diagnosis, "[w]hite folks has got a theoretical knowledge of prejudice" and they must acquire "a real one." 180 Once again, a plausible theory of equality must be driven by actual experiences on the ground.

By suffering through the indignities of prejudice firsthand, whites might finally understand what is wrong with Jim Crow and become moved to eliminate it. Experiential learning about racism would teach Northern whites that true equality means something more than civility:

It is not enough for white folks just to be nice and shake my hand and tell me I am equal. I know I am equal. What I want is to be treated equal. So maybe if the nice white folks really find out what it is like not to be treated equal-after they live Jim Crow themselves-I bet you, things will change! You know, white folks would not put up with Jim Crow-if they ever got Jim Crowed themselves. ${ }^{181}$

For Simple, the privilege of citizenship imposes on whites a "duty to find out" the full extent of their own constitutional violation, and "duty cannot be snooty." 182 Self-scrutiny must be undertaken with a measure of humility, otherwise moral lessons are not likely to take. When knowledge of injustice is honestly and viscerally acquired, there can be little choice left but to spring to action. In its earliest iteration, a reversal of fortune is merely suggested, a voluntary test of one's democratic commitment.

\footnotetext{
179. HUGHES, Duty is not Snooty, supra note 123, at 29.

180. Id. at 31 .

181. Id. at $31-32$.

182. Id. at 32
} 
Soon enough, the author's idea of role-reversal is developed into a fullscale remedy for dealing with recalcitrant white Southerners and for bringing a measure of justice to aggrieved black citizens. In Promulgations, ${ }^{183}$ Simple contemplates what he would do if he "was setting in the High Court in Washington." 184 He declares, "I would bang my gavel and promulgate" law, followed by additional "promulgations that would take place if people did not obey my laws." 185 In a swipe at the sitting Justices for their cowardice, Simple promises not to "be paid a big salary just to read something off a paper." 186 He would metaphorically take to the streets to ensure compliance with the Constitution: "I would gird on my sword, like in the Bible, and prepare to do battle." 187

The Equal Protection Clause would be interpreted according to the Christian maxim: "Love thy neighbor as thyself."188 From John Brown to Martin Luther King, Jr., popular legal theorists have often urged such a love-centered theory of equality. At the same time, conjuring the Old Testament vision of justice allows Simple to propose remedies from which the Warren Court would surely cringe, in the name of a benevolent vision of law. Girding on the sword evokes Jesus's call to render popular judgment: "[I]f you have no sword, sell your cloak and buy one." 189 Simple's judgment, rendered with humility but without remorse, "will pierce your soul . . . so that the secret thoughts of many may be laid bare."190

According to the jurisprudence of the common man, the most effective remedy for transgressing higher law would be court-ordered role reversal: "The first man I caught who did not love his neighbor as hisself, I would make him change places with his neighbor-the rich with the poor, the white with the black, and Governor Faubus with me."191 The injunction echoes Jesus of Nazareth's teaching that "the last will be first, and the first, last," a Christian judgment in which the powerful and powerless ultimately trade places. ${ }^{192}$ But Simple is not concerned with the End of Days; he is

\footnotetext{
183. Langston Hughes, Promulgations, in Simple’s UnCle SAM, supra note 1, at 160, 160.

184. Id. at 160

185. Id. at 160 .

186. Id.

187. Id.

188. Id.; see also Mark 12:31 (New Jerusalem Bible).

189. Luke 22:36-38 (New Jerusalem Bible) ("He said to them, 'But now if you have a purse, take it, and the same with a haversack; if you have no sword, sell your cloak and buy one, because I tell you these words of scripture are destined to be fulfilled in me: He was counted as one of the rebellious."').

190. Luke 2:34-35 (New Jerusalem Bible). The sword motif is a strong one in Christian accounts of judgment: "'Do not suppose that I have come to bring peace to the earth: it is not peace I have come to bring, but a sword." Matthew 10:34-35 (New Jerusalem Bible). To be effective, justice must be powerful enough to reconfigure social boundaries, with the capacity to "set son against father, daughter against mother, daughter-in-law against mother-in-law; a person's enemies will be the members of his own household." Matthew 10:35-36 (New Jerusalem Bible).

191. HuGHES, supra note 202, at 160.

192. Matthew 20:16 (New Jerusalem Bible). See also Mark 10:31 (New Jerusalem Bible) ("Many who are first will be last, and the last, first."); Luke 13:30 (New Jerusalem Bible) ("Look, there are those now last who will be first, and those now first who will be last.").
} 
interested in fashioning justice within the bounds of secular law. Only through such an ironic change in fortunes in this life would a violator experience loss, shame, remorse - all of the emotions that would need to be returned to white folks who have for so long propped up a legal system that dehumanized their fellow man.

Simple explains that he "would make Governor Faubus go to school again in Little Rock and study with them integrated students there and learn all over again the facts of life." 193 There, he would not only have to experience the very race mixing that he despises, but also learn his constitutional history:

I decrees now and from here on out that you straighten up and fly right. Cast off your mask of ignorance and hate and go study your history. You have not yet learned that 'taxation without representation is tyranny,' which I learned in grade school. You have also not learned that "all men are created equal," which I learned before I quit school. Educate yourself, Faubus, so that you can better rule your state. ${ }^{194}$

The very thought of Orval Faubus, forever the angry face of segregation, forced to sit with black students in a school house is beyond hilarious. Simple's desegregation order emerges from a jurisprudence of the literal, where the violator of equality is forced bodily to endure the race mixing he so deplores. In Simple's clever hands, the nation's fundamental laws would not be rendered impotent through timid toleration of white resistance, but would instead become a resilient instrument capable of ensuring political justice.

If he had the power to enforce the Constitution, Justice Simple would not be above trickery. In the event Faubus defied the decree, Simple would whisper in the Governor's ear that secret records show he has colored blood. "I am your third cousin," Simple the trickster-judge would tell him. ${ }^{195}$ "Whilst he was fainted," Simple goes on, "I would pick him up and take him to a mixed school. When he came to, he would be integrated."196 And that would be that.

In this incarnation of poetic justice, Simple goes well beyond Nussbaum's ideal of the judge as "[i]ntimate and impartial, loving without bias." ${ }^{197}$ For her humanistic conception of judging, Nussbaum draws on Walt Whitman's suggestion that the judge must "see[] eternity in men and women."198 To Simple, however, democratic justice requires something more than sensitively rendered justice or the ability to appreciate the complexity

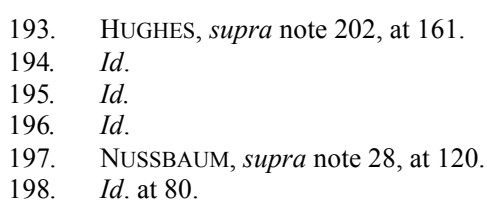


of life. Dignity is an important idea, but one that requires a serious commitment of institutional resources for its protection. Because of Simple's belief in equality as a powerful ethical ideal and not just a matter of proper conduct, justice demands a willingness to use state authority creatively to destroy the social foundations of hatred. ${ }^{199}$ As Simple puts it, "Rev. Martin Luther King tries to pray prejudice out, but sometimes I think we are gonna have to flay it out."200

Thus, Hughes would almost certainly reject Nussbaum's model of compassionate judging as incomplete. By employing the reversal of fortune motif, the author harkens to an older vision of justice in which the morally bankrupt face an ignominious end in a manner that matches their transgressions. Virtue, too, must be rewarded - something not guaranteed by a judge merely moved to exhibit compassion. In one fantasy sequence, Simple heralds a "new day" when believers in white supremacy "will be cut down to size." ${ }^{201}$ He suggests that racism arises from a deep-seated sense of status anxiety, but if the world no longer pays oppressors the same kind of attention and respect, "the white man is going to get so bugged he will go to pieces, start trembling and shaking, frothing at the mouth, and be so dizzy in the head that he will fall down and faint in front of them schools from which he has barred Negroes out." 202 At that point, "Negroes will just walk on in school and set down and start studying." When whites call to be helped up, blacks "will be too busy getting [their] arithmetic." 203

The twist given by Hughes to this older conception of justice is twofold: poetic justice is transitional and its ultimate object is to civilize democratic citizens. It recalls the judgment rendered in Dante's Inferno, ${ }^{204}$ where through an "infernal irony" sinners are sentenced to undergo visceral punishments commensurate with their offenses against divine law. ${ }^{205}$ Yet Hughes is concerned not with eternal punishment, as Dante was, but rather with democratic justice in the here and now. He does not call on white citizens to abandon hope, but rather wishes to adjust their attitudes and expectations through compelled self-inquiry. ${ }^{206}$ Eventually, the white man will wake up from his fainting spell to find blacks newly "hale, hearty, and fit to tell him off." 207 On the other side of the ledger, Simple seeks to restore some measure of hope to black Americans. He never consigns whites to "eternal grief" for their wrongs, but instead pursues civic reeducation and

\footnotetext{
199. LAngSton Hughes, Flay or Pray?, in SimPle’s UnCle SAM, supra note 1, at 118, 118-20.

200. Id. at 119. Simple's actions suggest that righteous rage is sometimes necessary to meet oppressive force. When Boyd observes, "You don't believe in Rev. King's policies of nonviolence," Simple retorts: "Only for the nonviolent. . . . If I lived down South, I would lose my temper." Id.

201. HuGHES, supra note 91 , at 70 .

202. Id. at 71 .

203. Id.

204. DANTE AlighiERI, THE INFERNO OF DANTE ALIGHIERI (Ciaran Carson trans. 2002).

205. John FreCCERO, DANTE: THE POETICS OF CONVERSION 93-109 (1986).

206. HUGHES, supra note 91 , at 69-72.

207. Id. at 71 .
} 
atonement. $^{208}$ "If I were a judge I would not put nobody to death," he explains. ${ }^{209}$ "I would just sentence the bad in them to die." $" 210$

After all, as a judge he would be doing only what generations of whites had demanded of blacks in civilizing them before extending the rights of citizenship. Thus, Simple's strategy of poetic justice is tempered by republican sentiments and the possibility of civic redemption. It is borne not out of vengeance but of restoration. Justice is constrained by a desire to break down illiberal attitudes and reintegrate the remade citizen in a new constitutional order founded on charity and opportunity. Now that the shoe is on the other foot-how can whites be heard to complain?

Closing the gap between constitutional ideal and lived experience is a persistent refrain in the stories. ${ }^{211}$ From the perspective of ordinary people, equal protection of the law is a grossly under-enforced right. In Color on the Brain, Simple contrasts the work of the High Court in striking down racial barriers with the long-held attitudes of white Southerners:

[W]ith white people, their left hand don't always know what their right hand doeth. ... Meaning that their right hand, which is really the hand that is trying to do right-by which I mean the Supreme Court-has done decreed the end of Jim Crow. But most white folks down South is nowhere near ready to go to school with me, let alone set on a bus seat with Negroes. ${ }^{212}$

Simple's diagnosis of the body politic claims hypocrisy on the part of decisionmakers or, at the very least, legal inconsistency (while recognizing congruence between legal outcomes and regional culture). Whatever the alchemy of factors reinforcing democratic injustice, it will take a significant effort - more than judicial decrees alone - to ensure equal protection of the law. One thing is certain: the Supreme Court has earned the wrath of diehard segregationists. This alone suggests the possibility of legal change. Cracker Prayer ${ }^{213}$ pokes fun at such extreme reactions by imagining an "old cracker" praying to the Lord to be delivered from integration. ${ }^{214}$ The last thing he wants to see are "Nigras lined up telling me the Supreme Court has decreed integrated seats in the Celestial Chariot, too."215 The prayer ends with the white supremacist defiantly telling the Lord that if his ride to Heaven has been integrated, he would rather risk God's wrath and "elect to

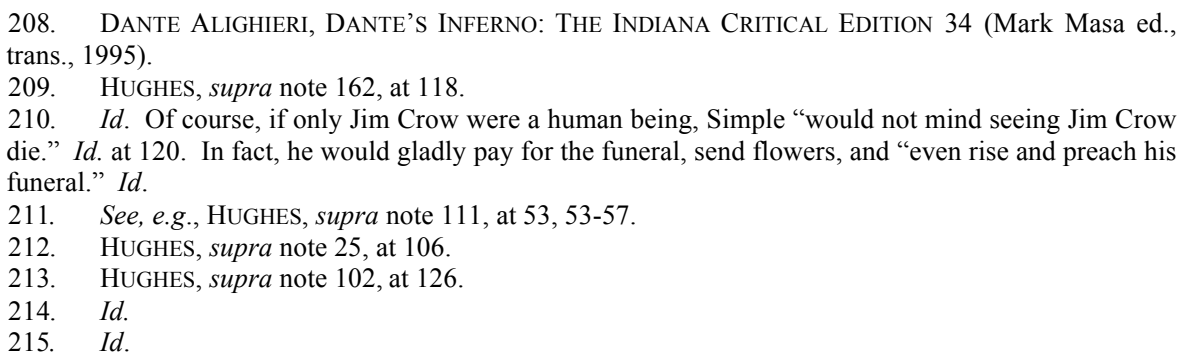


stay right here on earth where at least Faubus is on my side."216 Clinging to a world organized according to unjust ordinary law, defenders of racial sovereignty turn their backs to higher law.

At times, Simple gestures toward the High Court as a way to deflate people's expectations of solutions from above. With All Deliberate Speed $d^{217}$ takes its title from the Supreme Court's follow-up ruling to Brown. ${ }^{218}$ In the story, Simple analyzes the angry burst of Southern defiance of judicial edicts. $^{219}$ Channeling the Whiggish belief that "Democracy grows in an ever-widening arc,",220 Boyd counsels Simple to adopt the long view and predicts eventual compliance with the Court's desegregation rulings. ${ }^{221}$ Boyd announces confidently that" [o]nce the stone is dropped in the waterin this case the Supreme Court decision regarding the schools- the circles of decency begin to spread and the healing waters to lap the shores of prejudice and wash away the sands of intolerance." 222 He is not alone in pronouncing the Court's efforts to promote equality as reasonable, gradual, and the safest answer to minimize Southern revolt. ${ }^{223}$

Simple takes a "darker" view. Against those who smugly tout gradualism, he pessimistically points out: "That adjustment period . . . will be a lulu!"224 Unrest will follow regardless of whether defiance is brooked. In fact, resistance could actually get worse because of the Court's show of weakness. A ruling intended to preserve order rather than mete out democratic justice will in fact embolden white folks who "do not have all these fine manners you read about in 'Gone With the Wind,' and they do not pay no attention to the law if they don't want to."225 Some brave black kids "will go tipping in, but flying out" as a result of segregationists" "unceremonious" behavior in defying the highest court of the land. ${ }^{226}$ What Hughes offers, then, is the everyman's rejection of a jurisprudence calculated to accommodate backlash politics. ${ }^{227}$

\footnotetext{
216. Id.

217. HUGHES, supra note 91, at 67.

218. Brown v. Bd. of Educ., 349 U.S. 294 (1955)

219. HUGHES, supra note 91, at 67.

220. HuGHES, supra note 91 , at 68.

221. Id.

222. Id.

223. See, e.g., Robert A. Burt, The CONSTitution IN CONFlict 29 (1992) (commending the Brown Court for navigating the stakes with "extraordinary agility, even artistry"); Philip Elman \& Norman Silber, The Solicitor General's Office, Justice Frankfurter, and Civil Rights Litigation, 1946-1960: An Oral History, 100 HARV. L. REV. 817, 827 (1987) (claiming he originated the phrase "with all deliberate speed" and that "it offered the Court a way out of its dilemma, a way to end racial segregation without inviting massive disobedience, a way to decide the constitutional issue unanimously without tearing the Court apart"); Jim Chen, Poetic Justice, 28 CARDOzo L. ReV. 581, 614 (2006) (defending both its accidental, literary genius as well as its effort to capture the social forces at work).

224. HuGHES, supra note 91, at 68 .

225. Id. at 69 .

226. Id. at $68-69$

227. For leading accounts of the backlash to Brown, see MichaEl J. Klarman, From Jim Crow to Civil Rights (2006); Gerald N. Rosenberg, The Hollow Hope: Can Courts Bring About SOCIAL CHANGE? (1991).
} 
"Until all deliberate speed catches up with a snail," Simple recommends that black parents in the South be allowed to attend school with their children to minimize shenanigans and protect loved ones. ${ }^{228}$ Even in the midst of razzing judicial elites, Simple has time to offer nuggets of common sense. He then turns to a discussion of the toll on the poor families who must undergo this prolonged transition period. As for himself, Simple says he will wait out the turbulence by staying in Harlem for fifteen or twenty years. "My children will go to school right here where it don't take no Supreme Court to get them in, and where I won't have to go to school with them every day whilst they are getting adjusted."229

Just as quickly as he warns of the delay tactics practiced by defenders of white self-governance, he veers off into a fantasy about how the dark people of the world will teach the defiant "down-home cracker" a lesson by ignoring him. ${ }^{230}$ Once the segregationist falls down in an apoplectic fit like a common bully deprived of the chance to relish the misery of his victims, blacks will enter the schoolhouse unobstructed and start studying furiously. The Supreme Court's formula for enforcement will then become upended, as blacks could get their education in peace while "let[ting] them Southerners lay there a few years on the cold, cold ground and get used to moderation." 231 Only then, "with all deliberate speed," should kindness be returned for evil. By that point, blacks might have regained some of their lost opportunities, along with the know-how to exploit them. In coopting the remedial formula, the author ingeniously informs readers that democratic justice must be about more than white comfort with integration. Time, if used wisely, is also crucial for black disappointment to wane and trust in white Americans and political institutions to be regained.

Intellectuals may laud the Warren Court for its statesmanship, but Simple sees "all deliberate speed" for what it is: a legal formula intended to promote incremental progress toward equality in actuality rewards footdragging by opponents of equality. Yet all is not lost. If only social conditions could somehow be completely subverted during the period of delay, and blacks could trade places with whites who have for so long benefited from policies of exclusion, then something approximating substantive justice might be achieved. Simple's perspective suggests the need for some sort of supplemental remedy for blacks who must suffer through such a long-term solution.

Invoking Eisenhower, Simple offers his own gloss on "all deliberate speed": "I would say, "These things take time. Let the people of good will of both races work it out, meanwhile you lay in the mud.",232 He would "let

\footnotetext{
228. HUGHES, supra note 91, at 69.

229. Id.

230. Id. at 71

231. Id.

232. Id. at 71. Simple thus offers a tongue-in-cheek answer to those who might say, enough with race-conscious remedies: Take a rest if you are exhausted! On the recurring claim of majorities expressing fatigue with racial issues, see Darren Lenard Hutchinson, Racial Exhaustion, 86 WASH. U.L. REV.
} 
them Southerners lay there a few years on the cold, cold ground and get used to moderation." $233 \mathrm{He}$ invites others to "visualize the Southern white man prone" while the Southern negro becomes "hale, hearty, and fit to tell him off." 234 Once again, he suggests a form of counter-subordination requiring the dramatic upsetting of social positions. The moment that whites recovered from their fainting spell, legal action would again be necessary to ratify any transformation. "The N.A.A.C.P. will have done carried my case to the Supreme Court, as usual . . and won again.,"235

After each side has had a chance to walk in another's shoes, in the shadow of the Constitution, the beginnings of reconciliation are possible. With right on their side, and having achieved some material gains, blacks would happily show compassion for their oppressors. Simple himself promises to "set in school and sing with all deliberate speed, 'I Shall Not Be Moved,' and I would ask the white folks outside to join in the chorus. After which I would invite them crackers into the schools to learn something too, because today they are just pure-D ignorant, that's all." 236 Roles would be reversed: blacks formerly excluded from education would teach whites, who would now have to learn the lessons of liberty and equality. Through this extended discussion, which is reminiscent of Jesus's own stories inverting social hierarchy, ${ }^{237}$ Simple adapts his notion of equality to encompass truly heartfelt action and an appreciation of past harm. With lacerating humor, he elevates the constitutional stakes of the fight over desegregation into a teaching moment.

Simple harbors other misgivings about integration as a general, and almost singular, objective. Even though elected officials, the NAACP, and jurists endorse desegregation as a model for achieving equality, Simple resents the fact that legal conflict has reinforced white people's tendency to see only "THE Negro, as if there was not 50-11 different kinds of Negroes in the U.S.A." 238 In Simple's frustration, one can detect a criticism of the unintended consequences of modern interest group activism. To create the sense of a political bloc, mobilize ordinary people, and influence official decisions, black leaders must claim to speak for the people. But this strategy has its drawbacks: it can depress contrarian sentiment, create the erroneous impression that all black Americans agree on a concept of the good life, and lead to complacency among whites once black leaders' demands are met.

In Coffee Break, Simple recounts a workplace conversation initiated by his white boss:

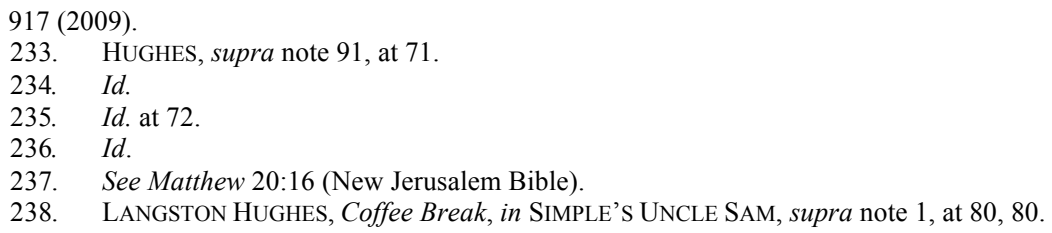


My boss says, "Now that you-all have got the Civil Rights Bill and the Supreme Court, Adam Powell in Congress, Ralph Bunche in the United Nations, and Leontyne Price singing in the Metropolitan Opera, plus Dr. Martin Luther King getting the Nobel Prize, what more do you want?"

"I am not THE Negro," I says. "I am me."

"Well," says my boss, "you represent THE Negro."

"I do not," I says, "I represent my own self."239

When Simple's boss insists that Ralph Bunche, Thurgood Marshall, Martin Luther King, Roy Wilkins, and James Farmer all represent him, Simple stresses the distance between these leaders and the common man. "I am proud to be represented by such men, if you say they represent me," he observes, "But all them men you name are way up there, and they do not drink beer in my bar." ${ }^{240}$ One should never confuse black leaders with the regular folks in whose name they act.

What is more, the lives of ordinary people, especially those who do not have children in Southern schools, feel far removed from the highly charged activities covered in the press and the priorities of black leaders spearheading legal transformation. Instead of being called "THE Negro"241 and understood as part of a collective, Simple demands that his individual concerns be met. "I am this Negro," he defiantly tells his employer, and he demands to "get out" of "[t]he jail you got me in." 242 His boss is puzzled, missing his employee's analogy of a low-wage job to an actual jail typifying Jim Crow conditions. In the white employer's view, once formal segregation has been overturned, democratic justice has been done. To Simple, Brown absolves white guilt and closes the door on the past.

The vignette also expresses anxiety that black leaders will not do enough to implement an ethical vision that would accomplish the most for all Americans. Because they do not drink in the same bar he does, and have never been seen on Lenox Avenue, Simple worries that elites might not appreciate the full range of problems afflicting the black community. $\mathrm{He}$ dissents from the tendency to flatten the black experience into a single narrative, a single set of concerns, and a narrow solution. It is instructive that Simple tries his best to dialogue with his white superior about the unintended consequences of in-group activist decisions, never giving up on the ideal of democratic debate. ${ }^{243}$ But it is also poignant that his personal effort to transcend the black-white divide on that occasion fails. The moment that Simple declares he wants something more than black students being admit-

$\begin{array}{ll}239 . & I d . \\ 240 . & I d . \\ 241 . & I d . \\ 242 . & I d . \text { at } 82 . \\ 243 . & I d .\end{array}$


ted to previously all-white schools, his boss announces, "The coffee break is over." 244

\section{THE LIMITS OF DIRECT ACTION}

Ultimately, Simple believes that the law can overcome generations of white supremacy and democratic injustice, but only through an array of popular efforts founded upon an ethical interpretation of the Constitution. Well into the 1960s, the courts struggled mightily over whether and how to protect mass protest through First Amendment law. ${ }^{245}$ Simple has a cleareyed view about the limits of mass protest. As momentum builds for civil rights laws and desegregation efforts, Simple begins to reflect some of the fatigue emerging in the community over civil rights. After protests and counter-violence "has been on the front pages of the newspapers for ten years," Simple observes that "some folks is getting so wrapped up in this integration thing, white and colored, that I do believe some of them is going stone cold crazy." 246 He paints an absurd picture of New Yorkers "talking to themselves on busses and in the subways, whirling around in the middle of the street, mumbling and grumbling all by themselves to nobody on park benches, dumping garbage on bridges ... running out of gas on crowded highways on purpose."247

Raising things to the level of farce, he shakes his head at news of a white minister who lays down behind a bulldozer rolling backwards rather than in front of it, where the driver might see him and stop in time. Simple objects to the unthinking protestor, as well as to the use of direct action as a knee-jerk response to every kind of social problem. ${ }^{248}$

Worried about the unintended effects of free speech, Simple acknowledges that the minister "were protesting Jim Crow-but sometimes the protest is worse than the Crow." "249 Beyond the possibility that activism has become undirected, Simple wonders if an individual's voice and dignity are lost in such mass displays. "It is not that I might be dying in a good cause," he explains, "but let me die on my own two feet, knowing where, when, and why, and maybe making a speech telling off the world - not in a wreck be-

\footnotetext{
244. Id.

245. See Edwards v. South Carolina, 372 U.S. 229 (1963) (finding that the arrests of a group of peaceful African American protestors did not breach the peach when they peacefully marched near State House in protest of discriminatory actions against African Americans); Garner v. Louisiana, 368 U.S. 157 (1961) (finding insufficient evidence to support claim that defendants breached peace by peacefully sitting at a business's whites-only lunch counter).

246. Hughes, Swinging High, in SimPle's UnCle SAM, supra note 1, at 4, 6-7. His concerns are magnified by a sense that "[t]he only time colored folks is front-page news is when there's been a race riot or a lynching or a boycott and a whole lot of us have been butchered up or arrested." LANGSTON Hughes, Name in Print, in Simple StaKes A Claim, supra note 19, at 140, 140.

247. HuGHES, Swinging High, supra note 267, at 6-7.

248. Id. at 7

249. Id.
} 
cause somebody has stalled a car whilst traffic is speeding. To me that is crazy!" 250

One day, it occurs to Simple that sit-ins and marches have lost their effectiveness through overuse. His solution is not to abandon direct action, but to spice it up. He quickly comes up with the idea of conducting "nudeouts": "Twenty million Negroes taking off every stitch-stepping out of pants, dress, and drawers in public places and posing in the nude" like Rodin's The Thinker "until civil rights have come to pass." "251 After painting the image of a nude James Farmer, Roy Wilkins, and Constance Baker Motley as "bare as Venus" stopping traffic, he predicts that this is the only way "America would be forced to scrutinize our cause." ${ }^{252}$ A nude-out would "shock America into clothing us in the garments of equality, not the rags of segregation. And when Negroes got dressed again, we could vote in Mississippi." ${ }^{253}$

When Boyd warns that "the Legion of Decency would have all of you in jail for indecent exposure," 254 Simple humorously raises the specter of a Due Process violation: "The colored cops in Harlem would be naked, too, so how would I know, without his uniform, that he were a cop?" 255 Lack of notice, Simple advises, will be their ticket to freedom. He gets the particulars wrong, of course, since he has not been trained as a lawyer; it is reasonable notice of the law's terms that Due Process requires, not actual notice that a police officer is watching. Through snickers, trained lawyers will detect one of the risks of popular constitutionalism, namely, the possibility that armchair theories of the Constitution will not match judges' interpretations. Even so, Simple is right about one thing: through sustained interactions between the people in the street and institutions, First Amendment law eventually embraced a broader view of mass protest. Along the way, jurists overturned scores of convictions on the ground that public order laws deprived protestors of proper notice of the law. ${ }^{256}$ And in a development that would no doubt delight Simple's creator and fans, the Supreme Court ultimately recognized public nudity as protected expression. ${ }^{257}$

The stories allow the author to work through concerns with legality and responsibility posed by manifest injustice. Simple sympathizes with black police officers ordered to arrest black participants during the civil rights

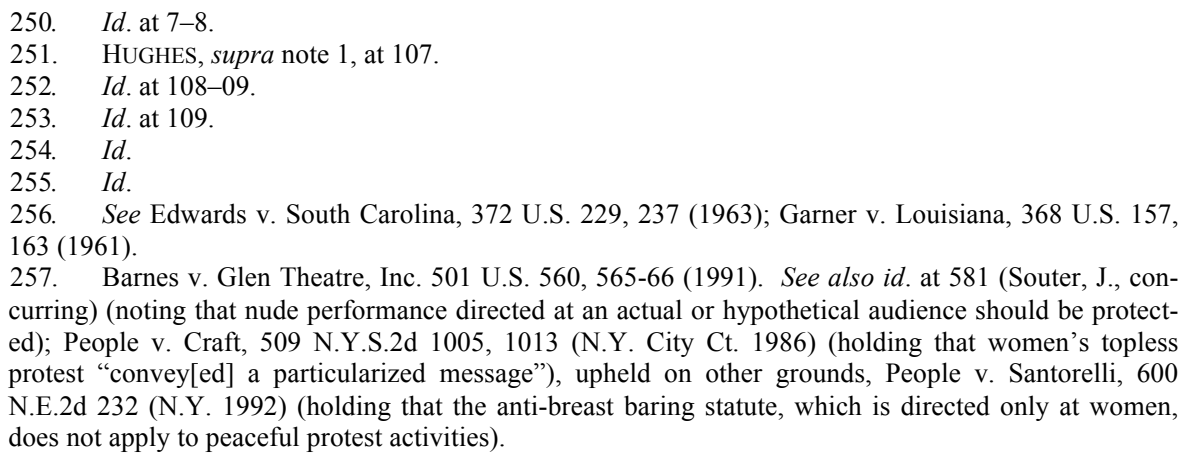
curring) (noting that nude performance directed at an actual or hypothetical audience should be protected); People v. Craft, 509 N.Y.S.2d 1005, 1013 (N.Y. City Ct. 1986) (holding that women's topless protest "convey[ed] a particularized message"), upheld on other grounds, People v. Santorelli, 600 N.E.2d 232 (N.Y. 1992) (holding that the anti-breast baring statute, which is directed only at women, does not apply to peaceful protest activities). 
struggle. How should black officers resolve their "double dilemma"- that they are obliged to enforce the law when their own civil rights align with the protestors' actions? ${ }^{258}$ Simple rejects the narrator's suggestion that the police force "should be color-blind",259 and enforce the law to quash the protests. Displaying a surprising facility with moral philosophy, he points out, "What is and what should be is two different things." 260 Simple does not deny that one must stake out a defensible normative position, but he insists that any normative position must be heavily influenced by the social reality in which the law operates. And that reality is one where police officers charged with enforcing the law routinely fulfill their obligation in a raceconscious fashion. ${ }^{261}$

The point is not whether to consider race or not in the abstract, since that is unavoidable. Rather, the central question is what to do in a world where law is already profoundly shaped by racial considerations. "So when a black cop sees me, he should not look through white eyes," Simple urges. ${ }^{262}$ "I am his brother-even when I am walking on a picket line and do not move fast enough to satisfy the police commissioner." 263 Once viewed in this light, it is an easy decision on the part of freedom-loving officers not to arrest any protestors: "When the law is not on the side of civil rights, then the law is not right, it's white." 264 Thus, Simple argues that any law that has been perverted by ideas of racial supremacy lacks moral authority. As such, protestors have a fundamental right to resist that law, and officers are excused from any obligation to enforce that law or any other law impeding a reunion of the moral and the legal.

At this point, it is apparent that Simple's ethical perspective on the Constitution justifies targeted lawbreaking, though it could be taken to rationalize stronger forms of popular disobedience. The author himself never goes there, and this notable silence distinguishes his program of legal reformation from projects of armed insurrection or black separatism that became increasingly attractive to some of his readers. Simple has little taste for open violence, and thus his tactics, like his substantive vision of the law, are bound by the moral-legal injunction to do no harm.

Because he views the Constitution on ethical terms, it allows him to put white resisters of desegregation and black protestors on different footing. Defenders of white sovereignty in the streets are subverting the legal order, Simple believes, while civil rights activists are on the right side of higher law despite what ordinary laws say. This is a distinction that a justice system abiding by neutral principles of governance has difficulty making, but

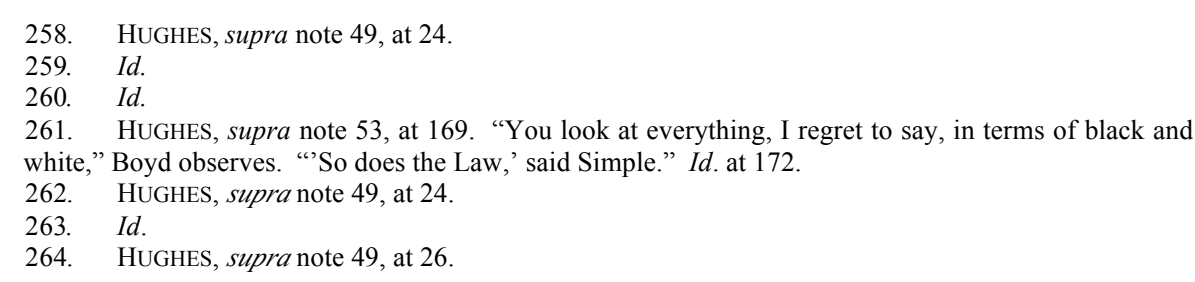


Simple suggests that, on a deeper democratic level, the content of one's expression matters. A just legal system must care about more than simply law and order; it must be able to distinguish between love and hate, virtue and vice, freedom and oppression.

\section{CRITIQUING SimPLE’s CONSTITUTIONAL VISION}

Langston Hughes's outlandish stories are primarily intended to subvert constitutional dogma and to stimulate political dialogue. Unconstrained by official duties or partisan allegiances, Simple presents a working man's theory of equality, adjudication, and freedom of expression. His irony-laced approach simultaneously permits and rewards a purity of thought. But how well does the author's approach satisfy other criteria for a constitutional theory beyond those of accessibility and coherence? For instance, if feasibility is one mark of a sound legal theory, to what extent could Simple's legal theories be implemented?

One risk involves the author's implication that taverns are, in some ways, effective sites of democratic engagement. Without coming out and saying so, Hughes's portrayal implies that in such alternative fora, the people can be more forthright, authentic, and committed. If we can depend upon our better selves to engage in deliberation, the stories suggest, this can only improve the quality of our political and legal ideas. Republican aims may be facilitated if citizens have places to which they can withdraw, contemplate the issues of the day, and formulate their own views.

Yet the danger is that the tavern remains a private refuge rather than a networked political site. If it is no more than a place for the disgruntled to vent, it may become a place for pooled despondency rather than a site of organized and effective discourse. At that point, it loses its function as a republican entity. In fairness, Simple never suggests that the tavern conversations should completely replace the public ones necessary to legal reform. And yet the broader challenge-one never explicitly answered by the stories - is how to ensure that ideas generated at the working man's bar of justice can actually impact the law's development in the light of day. Making effective connections between the various domains where legal knowledge is acquired is an elementary component of any plausible legal theory.

What of the author's interpretive approach to the Constitution? Throughout, Simple propagates an account of ethical sovereignty, that is, he looks upon America's founding principles as establishing certain collective values and contends that the continuing legitimacy of the law depends on fidelity to these shared mores. These beliefs not only animate the legal text, but also comprise the ties that bind citizens to one another. ${ }^{265}$ Simple is race

265. Ethical interpretations of the Constitution encompass Dworkin, who proposes an appeal to a shared liberal ethic, RONALD DWORKIN, LAW's EMPIRE (1986), to Sandel, who contends that a valuesbased approach to deciding socio-legal questions is not only unavoidable but also recognizes that people are first and foremost constituted by their ethical communities. MICHAEL J. SANDEL, DEMOCRACY'S 
conscious, believing that neutrality is a dangerous fiction, but he never gives up on the possibility of reconciliation and self-rule by a heterogeneous population.

Ethical theories of law are both popular and coherent. But they can founder on two kinds of objections: one lodged by the pragmatist and the other raised by the pluralist. Where the ethical approach treats the Constitution as a document embodying timeless values, the pragmatist understands the law to outline a working plan of government to solve problems. ${ }^{266}$ The pragmatist says that an ethical reading of the Constitution prizes ideological purity over realistic or empirically-driven solutions. ${ }^{267}$ Orthogonally, the objection of the pluralist emphasizes the force necessary to generate ethical change. Large-scale ethical transformation and lock-step conformity are not only impossible, the pluralist claims, but also requires too much violence to sustain in a heterogeneous society that respects plural conceptions of the good life. ${ }^{268}$ At best, some thin notion of civility, neutrality, or bounded respect, is what constitutes the people. This brings us full circle, as Simple himself challenges the liberal claim of neutrality as well as the efficacy of thin forms of affinity and political justice.

Many constitutional theories incorporate some ethical component, especially when interpreting the abstract promises contained in American legal texts. The differences between one theory and the next often turn on how single-minded one should be in pursuing an ethical reading of the Constitution and what sources should be drawn upon. This uncertainty over the role of an ethically-based Constitution is reflected in Hughes's own work. Simple's character is race conscious, and occasionally fantasizes about how black sovereignty can make the world a better place. But he consistently backs away from the full ramifications of a race-centered theory of selfgovernance. A major shift in values, outlooks, and beliefs is required by Simple's approach. But hard questions linger over just how far a government should go to reshape political beliefs, without destroying the baseline of respect and toleration necessary to maintain faith in a shared legal order.

Simple's vision of judging - one that turns to poetic justice as a means of implementing an ethical view of the Constitution - pushes hard against legal orthodoxy. It challenges the modern view of judging as the vindication of neutral principles or the institutional values of modesty and restraint. Instead, he offers a view of judging as brave, forceful, and righteous. His outrageous, and even farcical, efforts to reeducate whites so they can live

Discontent: America in Search of a Public Philosophy (1996); Michael J. Sandel, Moral Argument and Liberal Toleration: Abortion and Homosexuality, 77 CALIF. L. REV. 521 (1989).

266. See, e.g., Daniel Farber, Reinventing Brandeis: Legal Pragmatism for the Twenty-First Century, 1995 U. ILl. L. ReV. 163 (1995); Richard A. Posner, Pragmatic Adjudication, 18 CARDOZO L. ReV. 1 (1996); Margaret Jane Radin, The Pragmatist and the Feminist, 63 S. CAL. L. REV. 1699 (1990).

267. See e.g., Farber, supra note 288.

268. See, e.g., Michael Walzer, Spheres of Justice: A Defense of PluRalism and Equality (1983). I read Jim Fleming's defense of legal rights as promoting "deliberative autonomy" to be grounded in the necessity of baseline legal limits, as well as the background fact of pluralism. See James E. Fleming, Securing Deliberative Autonomy, 48 STAN. L. REV. 1 (1995). 
peaceably with black Americans will strike many jurists as risky, illconsidered, and perhaps a violation of individual autonomy. The vision of poetic justice works best not as a plausible approach in real cases, but rather as a dramatic way of providing context. Simple's stories portraying courtordered role reversal, material improvement, and atonement reveal just how modest the Supreme Court's actual remedies really have been. All the backlash, struggle, and noise accompanying desegregation have obscured the institution's lack of ambition for democratic justice.

The character's defense of creative forms of street protest is not only plausible, but also fits comfortably with the legal vision he has sketched. He rightly wonders whether the politics of mass spectacle can work for anything more than the most serious issues of the day. It might even be the case that First Amendment law has not kept up with the needs of mass protest and the strategies devised by the state to neutralize its effectiveness. But the distinction that Simple has drawn - where speech rights are vindicated when in the right but can arguably be quelled when speakers are in the wrong - may make sense from a purely moral perspective but simply cannot be enforced fairly. For it would invite judges to make moral judgments about the nature of one's expression rather than decide whether, on some other principled terms, the expression is valuable and expressed in a nondangerous fashion. ${ }^{269}$ Who is to say, moreover, that willful violation of ordinary law to defend equality is ethically correct, but legal disobedience is wrong when accomplished in the name of protecting property rights?

Simple's theory of equality holds the most promise. He is not alone in criticizing the Court for advancing an impoverished conception of equality, one that either focuses too narrowly on the appearance of progress or crumbles into unprincipled outcomes when pragmatic concerns are raised. Far too often, the empirically complicated world of inequality in America is avoided by legal decisionmakers who prefer immediate, concrete, and individualistic solutions. ${ }^{270}$ Nevertheless, his more robust theory of equality faces difficulties in becoming implemented. Race-conscious remedies, though they may be warranted, entail social costs. Simple intuitively recognizes this, even if he does not fully explicate it. What he seemingly recommends is to move from a transitional race-based remedy into one that centers on addressing economic inequalities, without abandoning the capacity to perceive and address racial injustice. Broadening the conception of equal protection of the law along these lines would serve not only school-age children, but all victims of racial discrimination. This is as much as

269. On the dangers of content and viewpoint discrimination, see Good News Club v. Milford Cent. Sch., 533 U.S. 98 (2001) and R.A.V. v. City of St. Paul, 505 U.S. 377 (1992).

270. See, e.g., McCleskey v. Kemp, 481 U.S. 279 (1987) (avoiding structural ramifications of holding racial inequities discovered in the application of the death penalty); Whren v. U.S., 517 U.S. 806 (1996) (forbidding judges from considering whether subjective racial intent played a role in stopping a motorist under the Fourth Amendment). 
Hughes, who struggled mightily with conflicting liberal and critical sentiments, could work out through literature.

It is not a far-fetched argument, and traditional liberals and critical theorists have all suggested a greater emphasis on class concerns. ${ }^{271}$ Where they often run into difficulties, however, concerns identifying the point at which explicit race-based answers are no longer necessary or worth the social costs, and ascertaining the kinds of economic solutions that can carry on the work of democratic justice.

If Simple's constitutional vision falters as a comprehensive legal alternative, it nevertheless does wonders as a mechanism for uncovering gaps in dominant theories and combating democratic heartbreak. For those denied justice in this world, the most pressing problems can be a sense of dislocation, a loss of faith in political institutions and even in the rule of law itself. Seen as a crucial element in the project of democratic recovery, Langston Hughes's stories shine. In the end, the author's belief in a higher law-the Golden Rule, the Constitution's promises of liberty, equality, and happiness - permit him to criticize without destroying. His writings create an imagined space for tending to one's political wounds while holding out the promise of recommitment. And yet, there can be so much disappointment and degradation to be endured. In such a gritty world, wit is a weapon, and ironic detachment is a survival tactic. They also serve as instruments of empowerment. In the right hands, a politics of irony can lay bare the very foundations of democratic injustice. Simple's stories suggest that laughter, more than tears, may keep alive hope for legal transformation.

271. See generally Richard D. Kahlenberg, The Remedy: Class, Race, and AfFirmative ACtion (1996); Margaret L. ANDERSEN \& PATRicia Hill Collins, RaCe, Class, and Gender: AN ANTHOLOGY (6th ed. 2006); Susan D. Carle, Debunking the Myth of Civil Rights Liberalism: Visions of Racial Justice in the Thought of T. Thomas Fortune, 1880-1890, 77 FordHAM L. REV. 1479 (2009); Laura T. Kessler, Getting Class, 56 Buff. L. REV. 915 (2008); Kimberle Crenshaw, Mapping the Margins: Intersectionality, Identity Politics, and Violence Against Women of Color, 43 STAN. L. REV. 1241 (1991). 